\title{
Feedback of tropical cyclones on El Niño diversity. Part II: possible mechanism and prediction
}

\author{
Qiuyun Wang ${ }^{1}$ · Jianping $\mathrm{Li}^{2,3,4}$
}

Received: 30 August 2021 / Accepted: 10 January 2022 / Published online: 14 February 2022

(c) The Author(s) 2022

\begin{abstract}
Part I of this study has shown that the tropical cyclones (TCs) over the western North Pacific (WNP) can affect El Niño diversity. In this part, we further explore the possible mechanism of this phenomenon: Compared with the composite situation of all El Niño months, when the preceding (3 months earlier) accumulated cyclone energy (ACE) is strong, the Walker circulation is further weakened and the east-west thermocline gradient is reduced. The eastward transport of warm sea water over the western Pacific is enhanced, the center of the maximum positive sea surface temperature (SST) anomalies is located in the equatorial eastern Pacific, supporting for the development of the eastern-Pacific (EP) El Niño. In contrast, compared with the composite situation of all El Niño months, when the preceding ACE is weak, the Walker circulation is enhanced and the east-west thermocline gradient is strengthened. Thus, the center of the maximum positive SST anomalies is limited to the equatorial central Pacific, supporting for the development of the central-Pacific (CP) El Niño. The modulation of thermocline depth by the WNP TCs mainly results from Kelvin wave propagation and Ekman pumping. In addition, WNP TCs are verified to contribute to the prediction of both the phase-locking of the peak of EP and CP El Niño events and the rapid decrease in SST anomalies during the decaying period of two types of El Niño.
\end{abstract}

Keywords Tropical cyclones $\cdot$ Accumulated cyclone energy $\cdot$ Western North Pacific $\cdot$ El Niño $\cdot$ Possible mechanism $\cdot$ Diversity

\section{Introduction}

El Niño-Southern Oscillation (ENSO) is characterized by the anomalous sea surface temperature (SST) variations in the equatorial central and eastern Pacific. Some theories and mechanisms were proposed for El Niño, which can

Jianping Li

ljp@ouc.edu.cn

1 Key Laboratory of Mesoscale Severe Weather/Ministry of Education and School of Atmospheric Sciences, Nanjing University, Nanjing 210023, China

2 Frontiers Science Center for Deep Ocean Multispheres and Earth System (FDOMES)/Key Laboratory of Physical Oceanography/Academy of the Future Ocean, Ocean University of China, Qingdao 266100, China

3 Laboratory for Ocean Dynamics and Climate, Pilot Qingdao National Laboratory for Marine Science and Technology, Qingdao 266237, China

4 Department of Atmospheric Sciences, University of Hawai' 1 at Mānoa, Honolulu, HI 96822, USA be broadly categorized into two perspectives: one is that El Niño is a self-sustained coupled ocean-atmosphere system (Bjerknes 1969; Suarez and Schopf 1988; Battisti and Hirst 1989; Jin 1997a, b; Picaut et al. 1997; Weisberg and Wang 1997; Wang et al. 1999b; Wang 2001). Another one is that El Niño is a stable mode triggered by stochastic forcing including the Madden-Julian Oscillation (Tang and Yu 2008), westerly wind bursts (Gebbie et al. 2007; Lian et al. 2014), the tropical instability waves (An 2008; Zhang 2014), monsoon activity (Zheng et al. 2014) and so on. With the deepening understanding of El Niño, the El Niño events that the center of SST anomalies occurs in the central Pacific has obtained plenty of attention. Thus, El Niño events are classified into at least two types based on the spatial distributions of SST anomalies, the conventional eastern-Pacific (EP) and central-Pacific (CP) El Niño (Ashok et al. 2007; Kao and Yu 2009; Kug et al. 2009). Some studies tried to reveal the possible mechanism of CP El Niño. They thought CP El Niño might result from the thermocline variations (Ashok et al. 2007), zonal advective feedback (Kug et al. 2009), westerly wind bursts (Chen et al. 2015; Fedorov et al. 2015) 
and subtropical forcing (Yu et al. 2010; Feng et al. 2014; Ding et al. 2017). Although those studies have proposed some different physical processes and impact factors of $\mathrm{CP}$ El Niño, just like Wang et al. (2016) summarized, "There is still much to learn about the dynamics of the CP El Niño and what causes the type of El Niño to vary and alternate over time.", there is still not a unified opinion on the mechanism of El Niño diversity (Yang et al. 2018).

Tropical cyclones (TCs) are spectacular and deadly meteorological phenomena (Emanuel 2003; Li et al. 2016), and also the focus of much researches (Chan 2000; Knutson et al. 2010; Kossin et al. 2014; Zhan et al. 2017; Guo and Tan 2018a, b; Kossin 2018; Wang et al. 2018, 2019a). TCs over the western North Pacific (WNP, $10^{\circ}-20^{\circ} \mathrm{N}, 135^{\circ}-170^{\circ}$ E) have been reported to affect El Niño intensity by atmospheric and oceanic processes (Wang et al. 2019b). And these WNP TCs have been proved that can help to shift the center of strongest SST anomalies 3 months later to the equatorial eastern/central Pacific, further favoring the development of EP/CP El Niño events (Wang and Li 2022) (hereafter Part I). Whether the WNP TCs can affect El Niño diversity by these two processes is the key issue concerned in this study. Moreover, owing to the initial errors and random atmospheric disturbances (Giese and Harrison 1991; Harrison and Vecchi 1997; Moore and Kleeman 1999; Wang et al. 1999a; Lian et al. 2014), El Niño predictability remains a key challenge. El Niño diversity increases the uncertainties of El Niño forecasting (Hendon et al. 2009; Jeong et al. 2012; Ren et al. 2016; Tang et al. 2018). Hence, another issue that we concerned is whether WNP TC activity can be applied to the El Niño diversity forecasting. Good prediction skill will further validate the findings in Part I of this study.

The outline of this paper is organized as follows: In Sect. 2, we provide a brief review of the data and methods in the analysis. Section 3 shows the atmospheric and oceanic bridges that the WNP TCs affect El Niño diversity. Section 4 shows an improved model for predicting El Niño diversity. Section 5 presents conclusions of the key results and corresponding discussion.

\section{Data and methods}

\subsection{Data}

WNP TC data from 1970 to 2018 is from China Meteorological Administration, this dataset is obtained from the International Best Track Archive for Climate Stewardship (IBTrACS) from the National Oceanic and Atmospheric Administration (NOAA) (available online at https://www. ncdc.noaa.gov/ibtracs/). And all recorded TCs are employed to study. Monthly $2^{\circ} \times 2^{\circ}$ SST data for the period 1970-2018 is taken from the Extended Reconstructed Sea Surface
Temperature (ERSST) V5 dataset (Huang et al. 2017) (available online at https://www.esrl.noaa.gov/psd/data/ gridded/data.noaa.ersst.v5.html/). Ocean variables are taken from the Simple Ocean Data Assimilation product (Carton and Giese 2008) (SODA 2.2.4) for the period 1970-2010 (available online at http://apdrc.soest.hawaii.edu/datadoc/ soda_2.2.4.php), with a horizontal resolution of $0.5^{\circ} \times 0.5^{\circ}$. Monthly wind and geopotential height datasets for the period 1970-2018 are from the National Centers for Environmental Prediction-National Center for Atmospheric Research (NCEP-NCAR) reanalysis dataset (Kalnay et al. 1996), on a $2.5^{\circ} \times 2.5^{\circ}$ global grid (available online at https://www.esrl. noaa.gov/psd/). The multi-model ENSO forecast data for the period 2002-2016 are from the International Research Institute for Climate and Society provided by Columbia University (IRI, available online at http://iri.columbia.edu/ forec ast/ensofcst/Data/). A three-month running mean is taken of all monthly datasets for the period 1970-2018 (1970-2010 for ocean data).

\subsection{Calculation of accumulated cyclone energy (ACE)}

Differing from the traditional ACE (Bell et al. 2000), the ACE in each $2^{\circ}$ latitude $\times 2^{\circ}$ longitude grid cell is calculated as:

$\mathrm{ACE}=\sum_{i} V_{i}^{2}$

where $V$ is its estimated 6-hourly maximum sustained surface wind speed (in knot) and $i$ is the $i$ th TC in a grid cell. Thus, the ACE index is defined as the anomaly of the sum of the ACE for all grid cells in the selected region $\left(10^{\circ}-20^{\circ}\right.$ $\mathrm{N}, 135^{\circ}-170^{\circ} \mathrm{E}$ ) (Wang and $\mathrm{Li} 2022$ ). The ACE index is used to define the strong (weak) ACE when its value is $\geq 0.5$ $(\leq-0.5)$ standard deviations.

\subsection{Definition of El Niño events and El Niño types}

The Niño-3.4 index is defined by the running 3-month mean of the SST anomaly in the Niño- 3.4 area $\left(5^{\circ} \mathrm{S}-5^{\circ} \mathrm{N}\right.$, $\left.120^{\circ}-170^{\circ} \mathrm{W}\right)$. El Niño events are selected on the basis of the NOAA standard (http://ggweather.com/enso/oni.htm). An El Niño developing year (January-December) is defined when El Niño develops from weak to strong, and an El Niño decaying year (January-December) is defined as a year when El Niño decays from strong to weak. Kug and Ham (2011) proposed a method to define El Niño diversity on the basis of the Niño-3 $\left(5^{\circ} \mathrm{S}-5^{\circ} \mathrm{N}, 90^{\circ}-150^{\circ} \mathrm{W}\right)$ and Niño-4 $\left(5^{\circ}\right.$ $\left.\mathrm{S}-5^{\circ} \mathrm{N}, 160^{\circ} \mathrm{E}-150^{\circ} \mathrm{W}\right) \mathrm{SST}$ anomalies. We take a similar approach, using the Niño-3 and Niño-4 indices during December-February. An EP El Niño event is defined when 
the normalized Niño-3 SST anomaly is greater than 0.5 and also greater than the normalized Niño-4 SST anomaly. A CP El Niño event is defined when the normalized Niño-4 SST anomaly is greater than 0.5 and also greater than the normalized Niño-3 SST anomaly. Thus, 5 EP El Niño (1972-1973, 1976-1977, 1982-1983, 1997-1998, 2015-2016) and 8 CP El Niño events (1977-1978, 1979-1980, 1994-1995, 2002-2003, 2004-2005, 2006-2007, 2009-2010, 2014-2015) are selected.

In addition, El Niño events are also divided based on the preceding ( 3 months earlier) ACE, including El Niño_ strong ACE (i.e. El Niño months associated with the preceding strong ACE) and El Niño_weak ACE (i.e. El Niño months associated with the preceding weak ACE). And composite El Niño month (i.e. composite of SST anomalies in the months which Niño-3.4 index is $\geq 0.5{ }^{\circ} \mathrm{C}$, in short, El Niño months) is employed to be compared with El Niño_ strong ACE and El Niño_weak ACE.

\subsection{Eastward propagation speed of Kelvin waves}

Step 1. Select two regions in plots of the spatial evolution of zonal thermocline depth (along $5^{\circ} \mathrm{S}-5^{\circ} \mathrm{N}$ ) anomalies during EP and CP El Niño events (Fig. 8). These two regions are defined by time and longitude. Region 1 (initial region) is $130^{\circ} \mathrm{E}-170^{\circ} \mathrm{W}$, and from January to March; Region 2 (final region) is $80^{\circ} \mathrm{W}-180^{\circ}$, from November to the following January;

Step 2. Find the maximum thermocline depth anomalies over the Regions 1 and $2\left(\operatorname{Max}_{1}\right.$ and $\left.\operatorname{Max}_{2}\right)$; this gives the initial (time ${ }_{1}$, longitude l $_{1}$ ) and final points (time 2 , longitude l $_{2}$ of Kelvin wave propagation, as a function of time and longitude.

Step 3. Kelvin waves propagate eastward when $\operatorname{Max}_{1} * \operatorname{Max}_{2}>0$; the propagation speed of Kelvin waves is given by the equation: (longitude ${ }_{2}-$ longitude $_{1}$ )/ $\left(\right.$ time $_{2}-$ time $\left._{1}\right)$.

\subsection{Modelling method}

The ACE + SST model in this paper is the improved version of the ACE+N3.4 model (Wang et al. 2019b). The period from 1970.01 to 1999.12 is defined as the base period; the anomalies of SST and ACE in the model are calculated relative to this base period. More details please see Appendix 1 .

\subsection{Other concepts}

Spatial similarity:

Step 1. Construct the observed and predicted spatial series with data for each spatial grid cell in the selected region.
Step 2. Calculate the correlation coefficient between two spatial series.

Sign consistency rate ratio of the number of grid cells in which the SST anomaly sign is predicted correctly to the total number of grid cells.

Leave-p-out Cross-Validation this method is one of the generalized cross-validation (GCV) (Geisser 1975). And the detailed description is also mentioned in Wang et al. (2019b). Here, it is applied to check of the ACE + SST model robustness.

Walker index $=\mathrm{U}_{200}-\mathrm{U}_{850}$, where $\mathrm{U}_{200}$ and $\mathrm{U}_{850}$ are the zonal wind anomalies at the 200- and 850-hPa levels, respectively.

Partial correlation analysis is employed to remove the linear signal of additional impact factors in the Sect. 3. In this study, these factors include the SST anomalies in the Niño-3.4 region and tropical western Pacific. In addition, SST anomalies after removing the preceding ACE in the Sect. 3.2.2 is obtained by removing the parts from the linear regression of preceding ACE on SST anomalies.

\section{Atmospheric and oceanic bridges responsible for the WNP ACE effect on EI Niño diversity}

From the perspective of the El Niño cases associated with the preceding strong and weak ACE events, Part I of this study (Wang and Li 2022) has revealed the strong (weak) ACE event could help to shift the center of the strongest SST anomalies 3 months later to the equatorial eastern (central) Pacific, further supporting the development of EP (CP) El Niño. Here, we still explore the possible mechanism based on these El Niño cases (El Niño months, El Niño_strong ACE and El Niño_weak ACE). To reveal the mechanisms of how the WNP TCs affect El Niño diversity, the concepts of atmospheric bridge and oceanic bridge (Lau and Nath 1996; Alexander et al. 2002; Liu and Yang 2003; Li et al. 2016; Li et al. 2019) are employed. Previous study (Wang et al. 2019b) has pointed out that the preceding WNP ACE affects El Niño intensity through two bridges: an atmospheric bridge and an oceanic bridge. Hereinto, the atmospheric bridge or atmospheric process changes the Walker circulation while the oceanic bridge or the oceanic process changes the thermocline depth. The change in the Walker circulation results from the lower-level anomalous westerlies and Hadley-like circulation related to TCs. In addition, Part I of this study (Wang and $\mathrm{Li}$ 2022) has demonstrated that the feedback of WNP TCs on El Niño diversity shows little dependency on the local SST anomalies (including in the Niño-3.4 region and tropical western Pacific), zonal wind anomalies over the tropical central-western Pacific and the Madden-Julian Oscillation, but they still affect the intensity 
of this feedback. Hereinto, Madden-Julian Oscillation show a very weak effect. And previous study (Wang et al. 2019b) has proved that $\mathrm{TC}$ occurrence can intensifies the westerly anomalies on the southern flanks of TCs. As a result, the role of the SST anomalies in the Niño-3.4 region and tropical western Pacific in the possible mechanisms are checked.

\subsection{Atmospheric bridge responsible for the effect of WNP TCs on El Niño diversity}

At lower atmospheric layer, 3 months before the El Niño months, the occurrence of TCs gives a center of low pressure anomalies over the key domain of ACE. There are negative meridional geopotential height gradient anomalies to the south of the key ACE region (Fig. 1a). When the El Niño_ strong ACE case occurs, the preceding pressure anomaly is lower over the key ACE region than that before the $\mathrm{El}$ Niño months because of the greater number of TCs in the WNP. The negative meridional geopotential height gradient anomalies to the south of the ACE region are therefore stronger 3 months before the El Niño_strong ACE (Fig. 1b, d). In contrast, when the El Niño_weak ACE case occurs, there are fewer preceding WNP TCs than that before the El Niño months, and the pressure anomaly is higher in the key ACE region. As a result, the negative meridional geopotential height gradient anomalies to the south of the ACE region are weaker 3 months before El Niño_weak ACE, even disappear (Fig. 1c, e). After removing the simultaneous influence of the SST anomalies in the Niño-3.4 region (Fig. 1f, g) or tropical western Pacific (Fig. 1h, i) on the anomalously geopotential height gradient, the changes of the anomalously geopotential height gradient 3 months before $\mathrm{El}$ Niño_strong ACE and El Niño_weak ACE with respective to El Niño months are still evident except for the weakening of intensity.

Varying with geopotential height gradient anomalies, the wind fields at lower atmospheric layer change. 3 months before the El Niño months, there are anomalous westerlies to the south of the key ACE region (Fig. 2a) associated with the tropical semi-geostrophic adjustment at 925-hPa related to the WNP TCs in Fig. 1a. In the El Niño_strong ACE case, the preceding anomalous westerlies to the south of the $\mathrm{ACE}$ region are stronger than before the El Niño months (Fig. 2b, d). This is because there are more WNP TCs 3 months before El Niño_strong ACE. In contrast, in the El Niño_weak ACE case, there are fewer preceding WNP TCs, and the anomalous westerlies to the south of the ACE region are weaker 3 months before El Niño_weak ACE (Fig. 2c, e). After removing the simultaneous influence of the SST anomalies in the Niño-3.4 region (Fig. 2f, g) or tropical western Pacific (Fig. 2h, i) on the anomalously zonal winds, the changes of the anomalously zonal winds 3 months before $\mathrm{El}$ Niño_strong ACE and El Niño_weak ACE with respective to El Niño months are still evident except for the weakening of intensity.

Except for the impact of the WNP TCs on the lower-level anomalously zonal winds by the semi-geostrophic adjustment processes, TCs could also lead to the anomalously meridional Hadley-like circulation (Wang et al. 2019b). 3 months before the El Niño months, there is an anomalous Hadley-like circulation with an ascending branch located in the Northern Hemisphere (Fig. 3a). In the El Niño_strong ACE case, the preceding anomalous Hadley-like circulation is stronger than that before the El Niño months (Fig. 3b, d). In contrast, in the El Niño_weak ACE case, the preceding anomalous Hadley-like circulation is weaker than that before the El Niño months, and almost disappears (Fig. 3c, e). After removing the simultaneous influence of the SST anomalies in the Niño-3.4 region (Fig. 3f, g) or tropical western Pacific (Fig. 3h, i) on the anomalously meridional Hadley-like circulation, the changes of the anomalously meridional Hadleylike circulation 3 months before El Niño_strong ACE and El Niño_weak ACE with respective to El Niño months are still evident except for the weakening of intensity.

Under the modulation of the WNP TCs on the lowerlevel anomalously zonal winds and meridional Hadley-like circulation, Walker circulation further changes. 3 months before the El Niño months, because of the anomalous westerlies at $925-\mathrm{hPa}$ level and the anomalous Hadley-like circulation with an ascending branch located in the Northern Hemisphere, there is an anomalously reversed Walker circulation (Fig. 4a), i.e. Walker circulation is weakened. This Walker circulation is further weakened 3 months before El Niño_strong ACE (Fig. 4b, d) because of the enhanced anomalous westerlies at $925-\mathrm{hPa}$ and the anomalous Hadley-like circulation with an ascending branch located in the Northern Hemisphere. The anomalous low-level westerlies related to the revised Walker circulation anomaly can reach to the east of $140^{\circ} \mathrm{W}$, which enhances the eastward transport of the warm sea water over the western Pacific. These features would be beneficial to the development of EP El Niño events. In contrast, the reversed Walker circulation anomaly weakens 3 months before El Niño_weak ACE (Fig. 4c, e) compared with that before El Niño months, i.e. Walker circulation is enhanced compared with that before El Niño months, and the anomalous low-level westerlies related to the reversed Walker circulation anomaly only reach $\sim 160^{\circ} \mathrm{W}$, which suppresses the eastward transport of the warm sea water over the western Pacific. This is because of the weakened anomalous westerlies at 925-hPa level and the anomalous Hadley-like circulation with an ascending branch located in the Northern Hemisphere 3 months before El Niño_weak ACE. These features would be beneficial to the development of CP El Niño events. After removing the simultaneous influence of the SST anomalies in the Niño3.4 region (Fig. 4f, g) or tropical western Pacific on the 

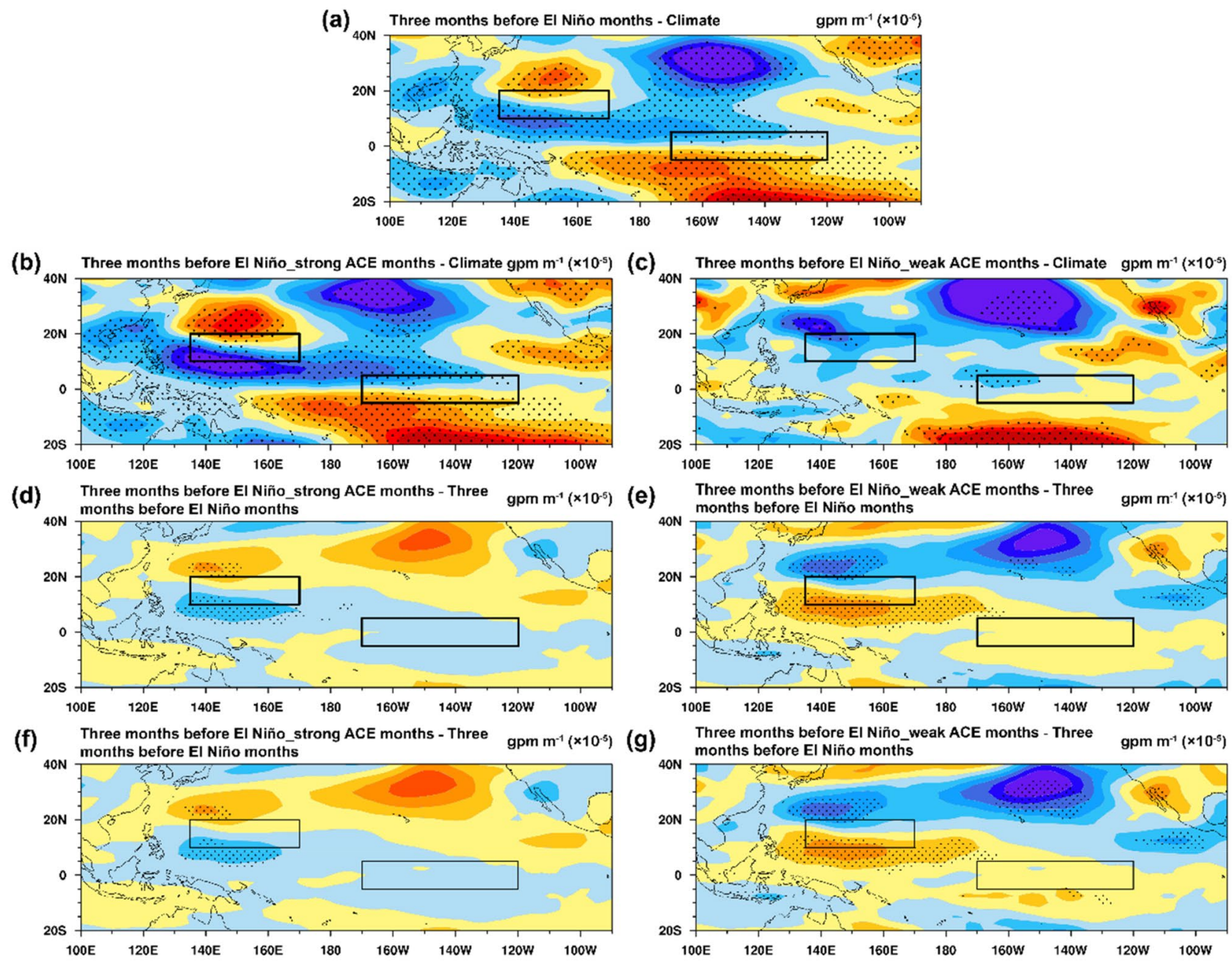

(h) Three months before EI Niño_strong ACE months - Three $\mathrm{gpm} \mathrm{m}^{-1}\left(\times 10^{\circ}\right)$
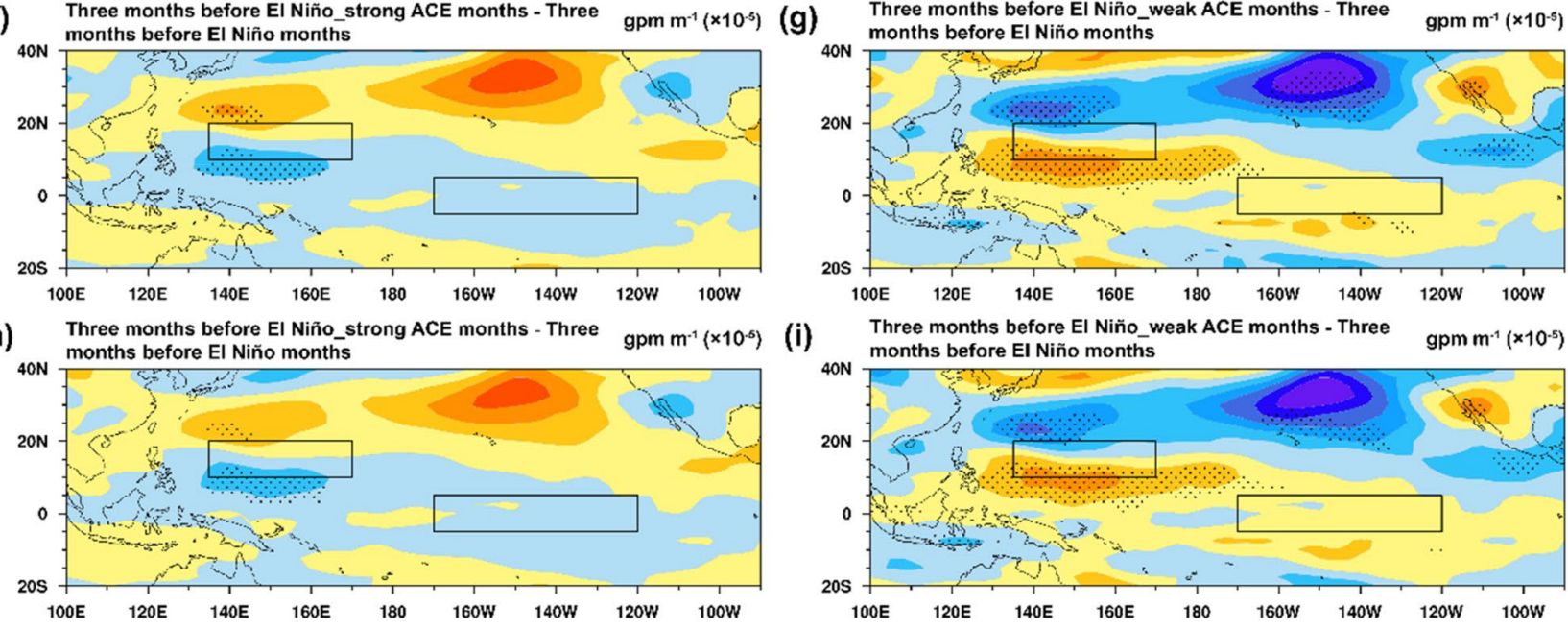

$\begin{array}{ccccccccccc}-0.5 & -0.4 & -0.3 & -0.2 & -0.1 & 0 & 0.1 & 0.2 & 0.3 & 0.4 & 0.5\end{array}$

Fig. 1 Composite of the 925-hPa meridional geopotential height gradient anomalies (shading, $\times 10^{-5}, \mathrm{gpm} \mathrm{m}^{-1}$ ) associated with different El Niño cases. a Composite of the 925-hPa meridional geopotential height gradient anomalies 3 months before El Niño months. The stippled regions denote statistical significance above the $95 \%$ confidence level (Student's $t$-test). The black rectangles denote the key ACE region $\left(10^{\circ}-20^{\circ} \mathrm{N}, 135^{\circ}-170^{\circ} \mathrm{E}\right)$ and the Niño-3.4 region $\left(5^{\circ} \mathrm{S}-5^{\circ}\right.$ $\left.\mathrm{N}, 120^{\circ}-170^{\circ} \mathrm{W}\right)$. b As in (a), but for El Niño_strong ACE case. c

Walker circulation (Fig. 4h, i), the changes of the Walker circulation 3 months before El Niño_strong ACE and El Niño_weak ACE with respective to El Niño months are still evident except for the weakening of intensity. Three months
As in (a), but for El Niño_weak ACE case. d Composite difference in the preceding meridional geopotential height gradient anomalies between El Niño_strong ACE and El Niño months. e As in (d), but for El Niño_weak ACE and El Niño months. $\mathbf{f}-\mathbf{g}$, As in $(\mathbf{d}, \mathbf{e})$, but the preceding meridional geopotential height gradient anomalies are those after removing the influence of the Niño-3.4 index. $\mathbf{h}-\mathbf{i}$ As in (d, e), but for that after removing the influence of the SST anomalies in the tropical western Pacific $\left(10^{\circ} \mathrm{S}-10^{\circ} \mathrm{N}, 120^{\circ}-160^{\circ} \mathrm{E}\right)$

later, this modulation of the Walker circulation by WNP TCs reaches its peak (Wang et al. 2019b).

The meridional distribution of the anomalous Walker circulation over the tropical Pacific gives more evidence 


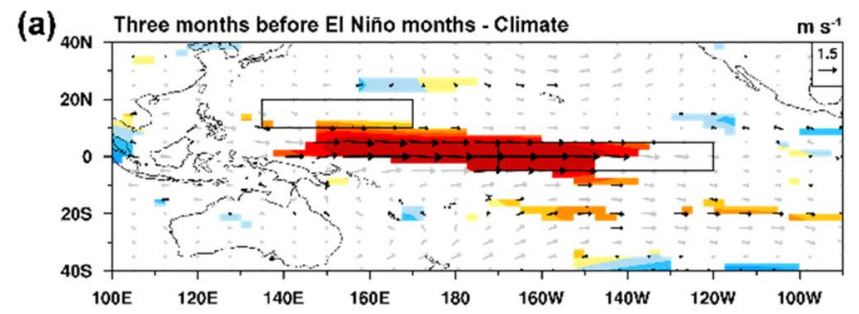

(b) ${ }_{40 \mathrm{~N}}$ Three months before El Niño_strong ACE months - Climate

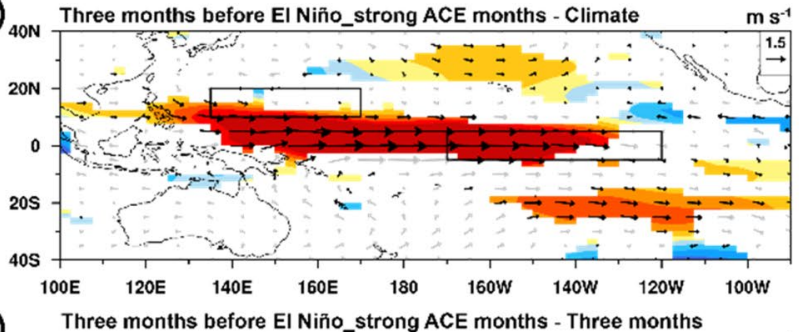

(d)

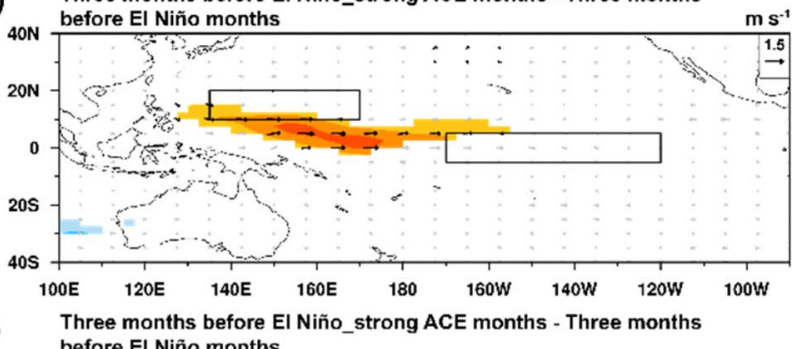

(f)

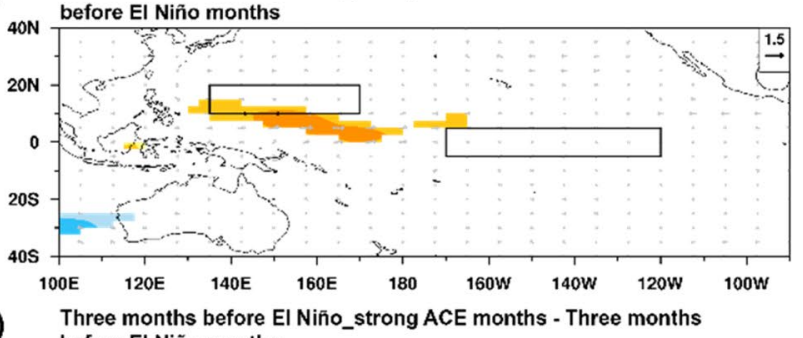

(h)

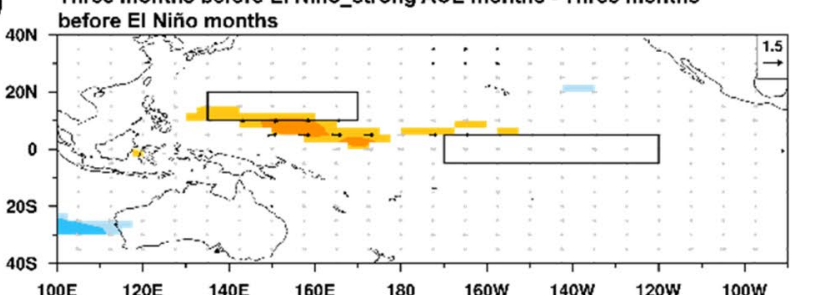

(c) ${ }_{40 \mathrm{~N}}$ Three months before El Niño_weak ACE months - Climate

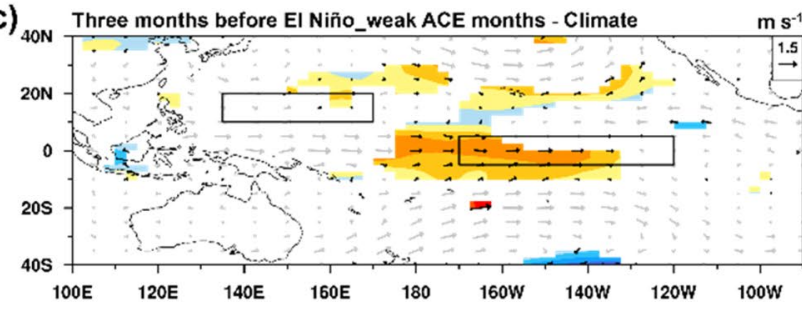

(e)

Three months before El Niño_weak ACE months - Three months

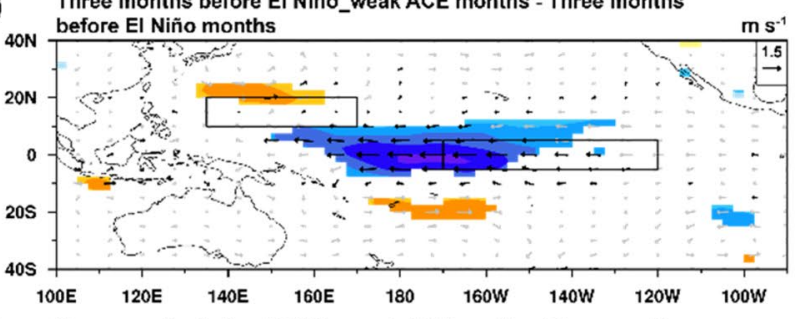

(g) Three months before El Niño_weak ACE months - Three months

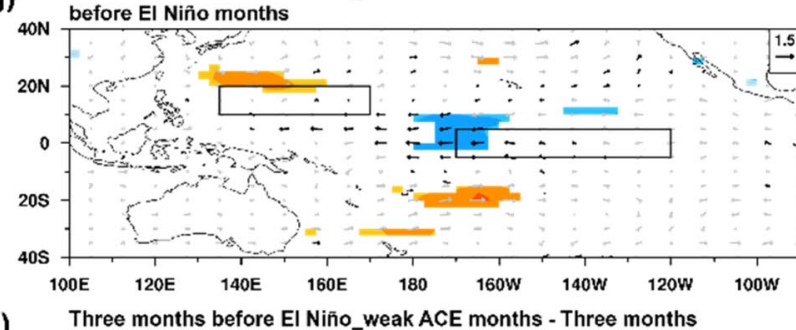

(i)

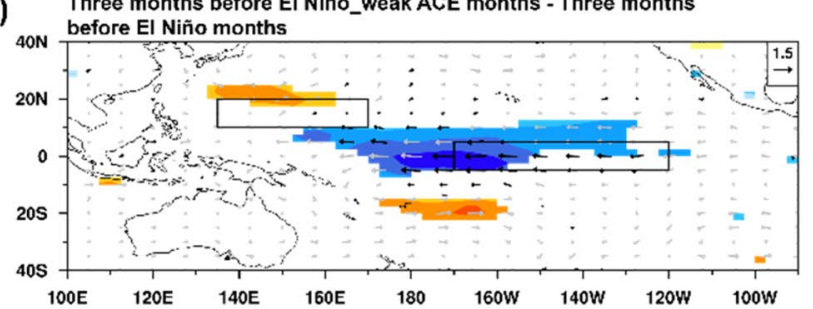

$\begin{array}{lllllllllll}-2 & -1.6 & -1.2 & -0.8 & -0.4 & 0 & 0.4 & 0.8 & 1.2 & 1.6 & 2\end{array}$

Fig. 2 As in Fig. 1, but for the zonal (shading, $\mathrm{m} \mathrm{s}^{-1}$ ) and horizontal wind (vectors, $\mathrm{m} \mathrm{s}^{-1}$ ) at 925-hPa. Shading and black vectors indicate significance above the $95 \%$ confidence level using Student's $t$-test

(Fig. 5). Compared with the situation of El Niño months, the weakened of the Walker circulation intensity is larger 3 months before El Niño_strong ACE (i.e. the revised Walker circulation anomaly becomes stronger 3 months before El Niño_strong ACE than that before El Niño months), particularly around $5^{\circ}-10^{\circ}$ equatorward of WNP TC key area (the key affected domain of WNP TCs) (Fig. 5a). 3 months later (Fig. 5b), with the adjustment of anomalous Walker circulation, and the area where the most significantly difference in anomalous Walker circulation between these two cases locates become symmetrical with respect to the equator. On the contrary, the weakened of the Walker circulation intensity 3 months before El Niño_weak ACE is smaller than that before El Niño months (i.e. the revised Walker circulation anomaly becomes weaker 3 months before El Niño_ weak ACE than that before El Niño months), particularly 

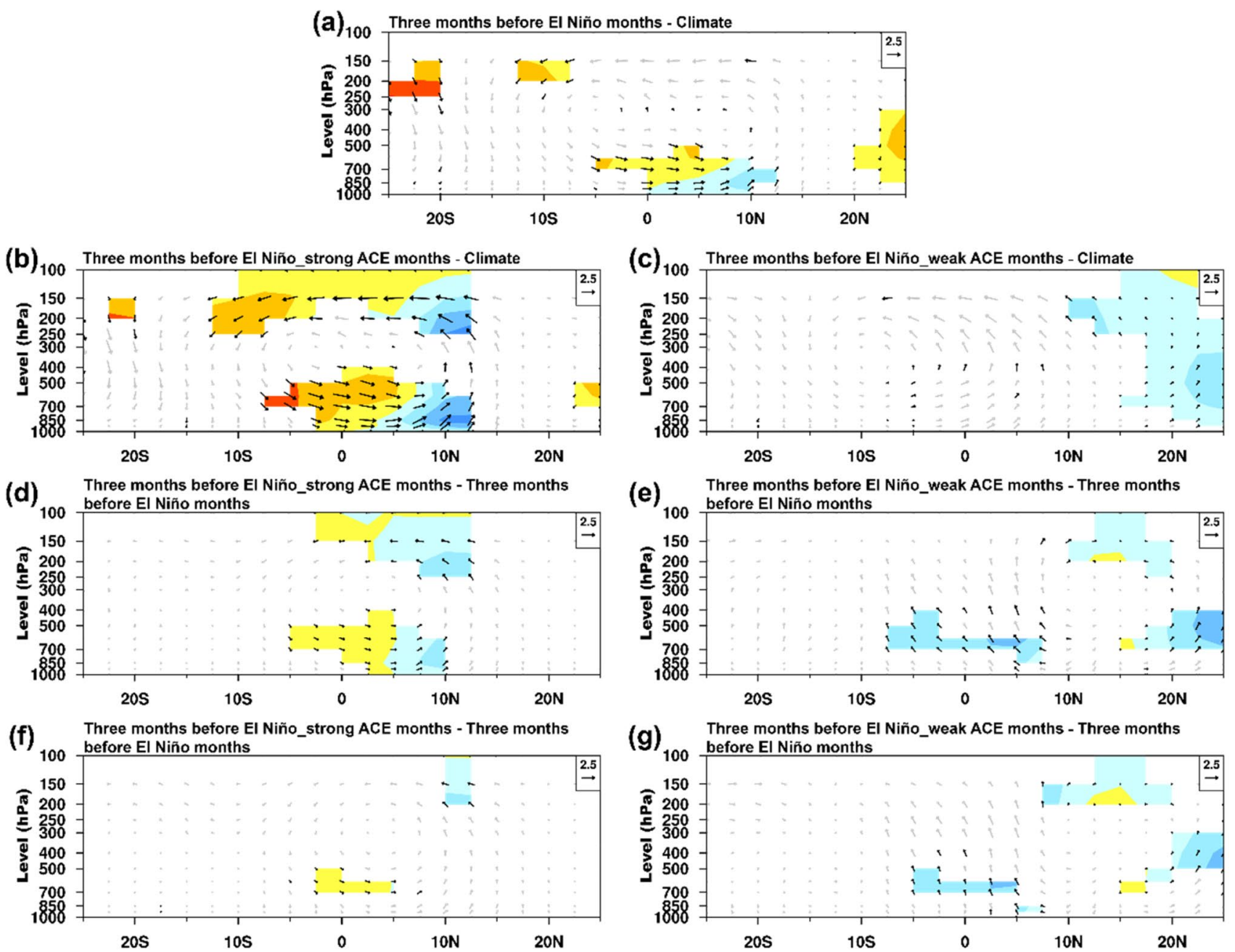

(g)
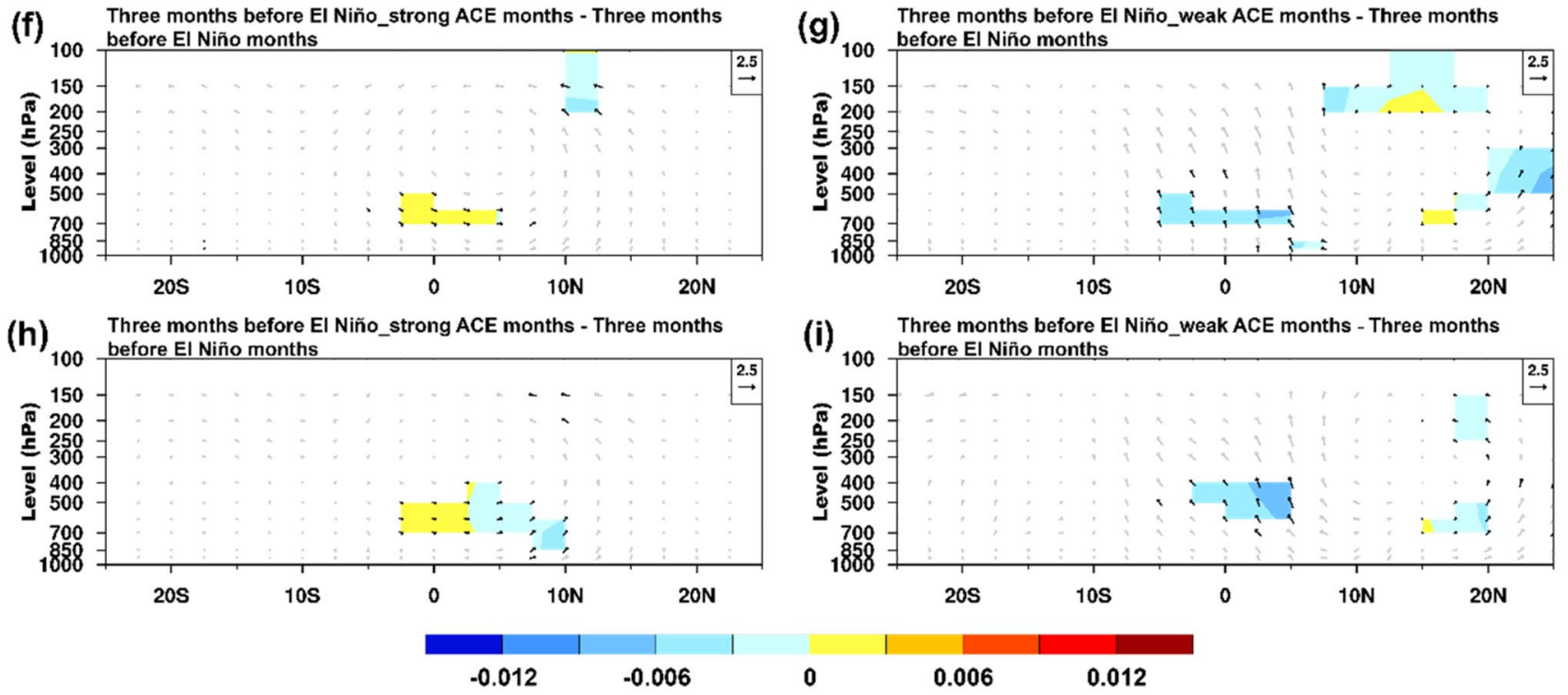

Fig. 3 As in Fig. 1, but for the vertical $p$-velocity (shading, $\mathrm{Pa} \mathrm{s}^{-1}$ ) and the wind (vectors) in the vertical-meridional plane over the WNP $\left(135^{\circ}-170^{\circ} \mathrm{E}\right)$. Vectors are obtained by the zonal wind anomalies (m

$\left.\mathrm{s}^{-1}\right)$ and magnified vertical $p$-velocity $(\times(-200))$. Shading and black vectors indicate significance above the $95 \%$ confidence level using Student's $t$-test

in the key affected domain of WNP TCs (Fig. 5a). Three months later (Fig. 5b), the area where the most significantly difference in anomalous Walker circulation from these two cases locates become symmetrical with respect to the equator.

\subsection{Oceanic bridge responsible for the effect of WNP TCs on El Niño diversity}

Wang et al. (2019b) demonstrated that the oceanic bridge or oceanic process by which the WNP ACE affects El Niño intensity is a change in the thermocline. In this section, we examine the effectiveness of this pathway in the modulation 


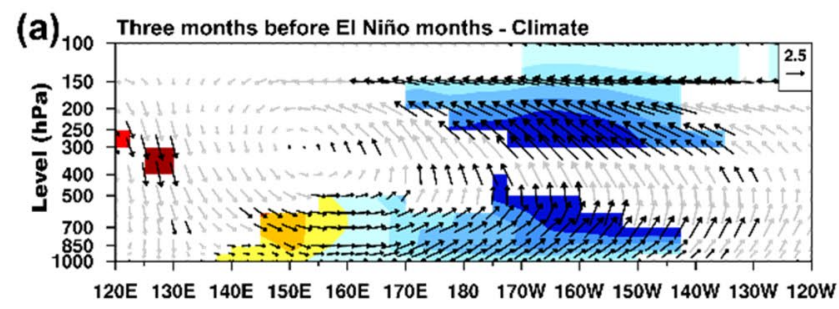

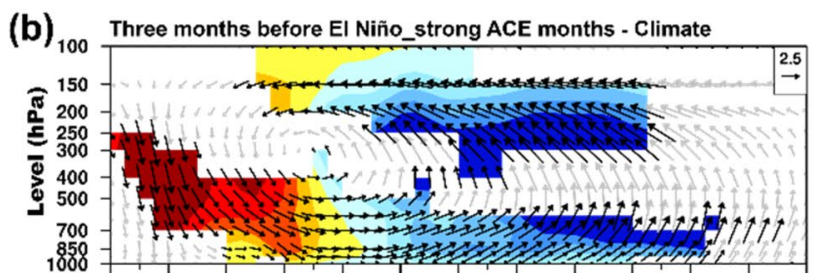

120E 130E 140E 150E 160E 170E 180 170W 160W 150W 140W 130W 120W
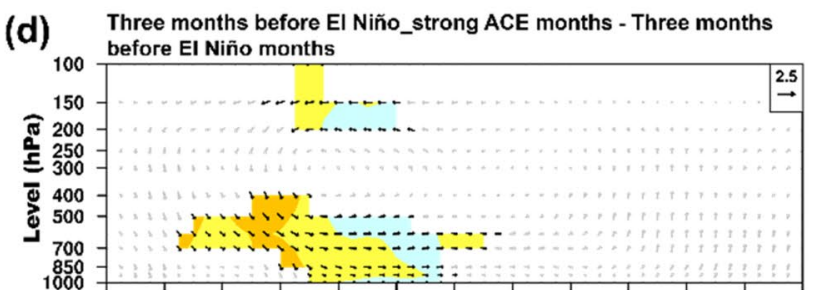

120E 130E 140E 150E 160E 170E 180 170W 160W 150W 140W 130W 120W
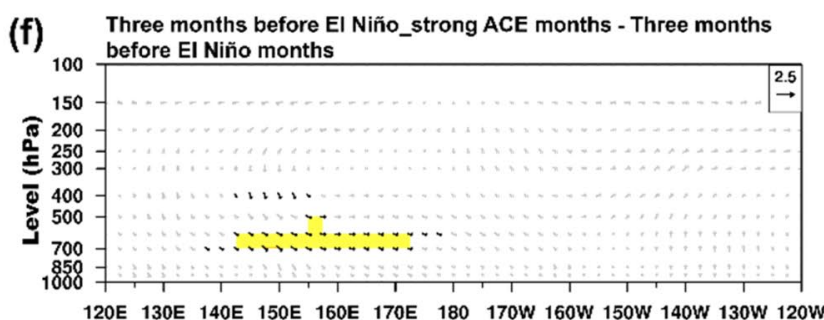

(h) Three months before El Niño_strong ACE months - Three months

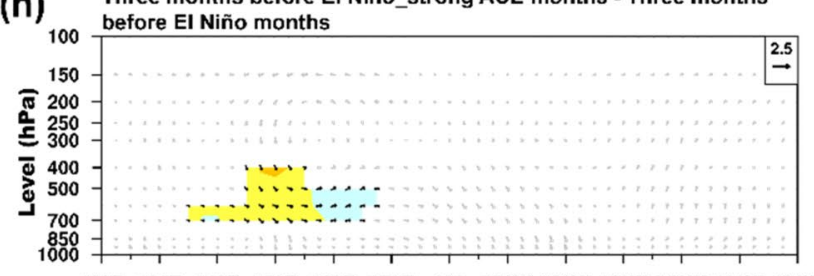

120E 130E 140E 150E 160E 170E 180 170W 160W 150W 140W 130W 120W

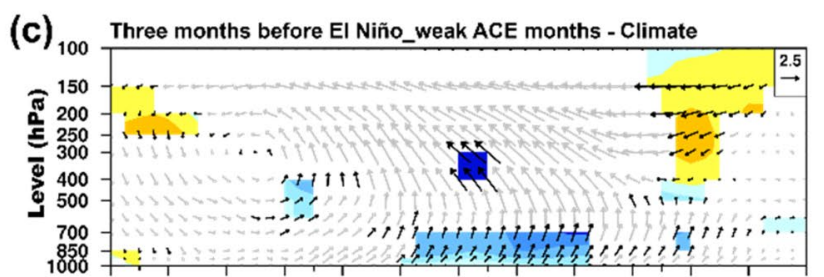

120E 130E 140E 150E 160E 170E 180 170W 160W 150W 140W 130W 120W

(e) Three months before EI Niño_weak ACE months - Three months

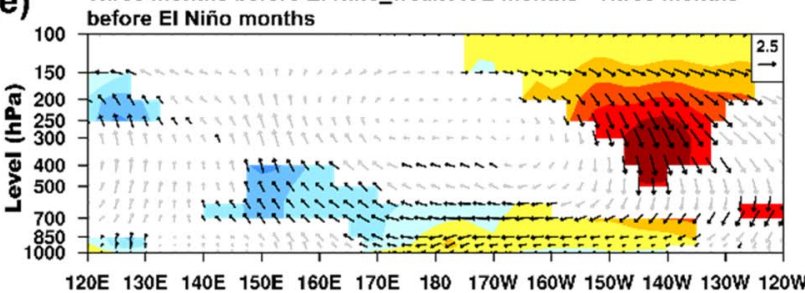

(g) Three months before EI Niño_weak ACE months - Three months

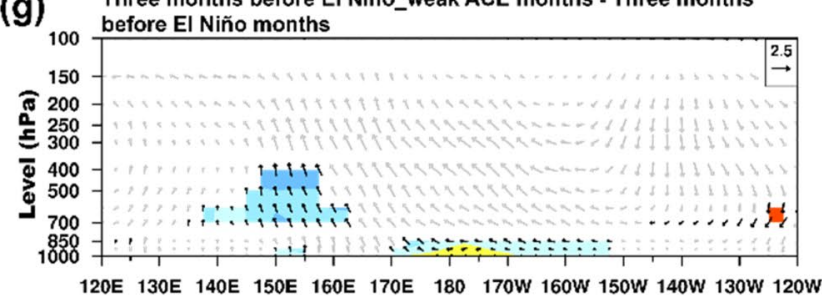

(i) Three months before El Niño_weak ACE months - Three months

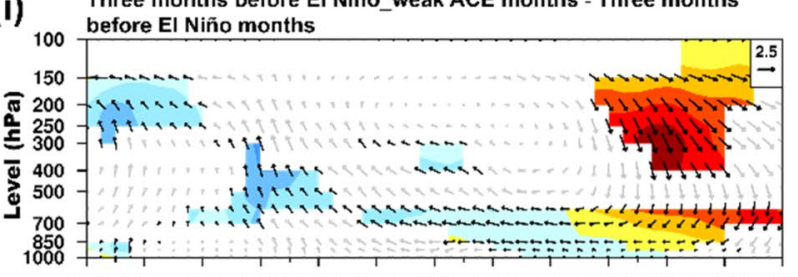

I20E 130E 140E 150E 160E 170E 180 170W 160W 150W 140W 130W 120W

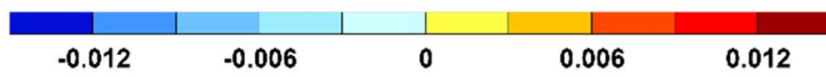

Fig. 4 As in Fig. 3, but for the vertical-zonal plane over $5^{\circ} \mathrm{S}-5^{\circ} \mathrm{N}$

of El Niño diversity. Moreover, the way in which TCs modify the thermocline is further explored.

\subsubsection{Modulation of the WNP TCs on the thermocline}

3 months before the El Niño months, the thermocline is shallowed over the western Pacific, and deepened over the eastern Pacific. The east-west thermocline gradient becomes small (Fig. 6a). In the El Niño_strong ACE case, because there are more preceding WNP TCs than that in the El
Niño months, the thermocline over the western Pacific is further shallowed 3 months before El Niño_strong ACE, especially in the area to the south of the key ACE region. The thermocline over the eastern Pacific becomes deeper and the east-west thermocline gradient smaller (Fig. 6b, d). That is, the east-west thermocline gradient is reduced 3 months before El Niño_strong ACE compared with that before El Niño months, which enhances the eastward transport of warm sea water, and the center of maximum positive SST anomalies is located in the equatorial eastern 

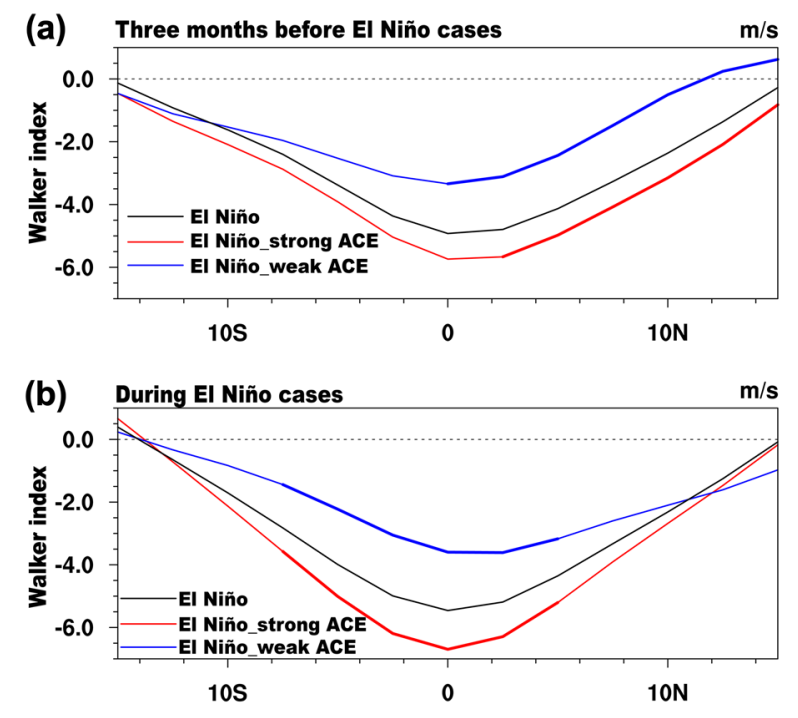

Fig. 5 Meridional composite (along $120^{\circ} \mathrm{E}-120^{\circ} \mathrm{W}$ ) of the Walker circulation anomalies $\left(\mathrm{m} \mathrm{s}^{-1}\right)$. a Composite of the Walker circulation 3 months before different El Niño cases. Black line is related to the El Niño months, red line for the El Niño_strong ACE and blue line for El Niño_weak ACE. b As in (a), but for during three El Niño cases

Pacific. These features would support the development of EP El Niño events. In contrast, in the El Niño_weak ACE case, there are fewer preceding WNP TCs than that in the El Niño months, and so the thermocline over the western Pacific is deeper 3 months before El Niño_weak ACE, the thermocline over the eastern Pacific is shallower, and thus the east-west thermocline gradient greater (Fig. 6c, e). That is, the east-west thermocline gradient is strengthened 3 months before El Niño_weak ACE compared with that before El Niño months. Thus, the eastward transport of warm sea water over the western Pacific is suppressed, the center of maximum positive SST anomalies is limited to the equatorial central Pacific, supporting the development of CP El Niño events. After removing the simultaneous influence of SST anomalies in the Niño-3.4 region (Fig. 6f) or tropical western Pacific (Fig. 6h) on the east-west thermocline gradient, 3 months before El Niño_strong ACE, WNP ACE can still lead a smaller east-west thermocline gradient than before the El Niño months, although the difference isn't significant. However, this insignificant difference doesn't affect that the warm sea water transports to the eastern Pacific, because the center of maximum positive SST anomalies also occurs in the equatorial eastern Pacific during the El Niño months (Wang and Li 2022). After removing the simultaneous influence of SST anomalies in the Niño-3.4 region (Fig. 6g) or tropical western Pacific (Fig. 6i) on the east-west thermocline gradient, the change of the east-west thermocline gradient 3 months before El Niño_weak ACE with respective to El Niño months is still evident except for the weakening of intensity.

\subsubsection{Process that the WNP TCs modulate thermocline}

The modulation of the thermocline by WNP TCs is further examined. The longitude of maximum thermocline depth anomalies moves eastward in the eastern Pacific with increasing WNP ACE anomalies for El Niño (Fig. 7). For EP El Niño (Fig. 8a), there is evident propagation of Kelvin waves during and after the TC season (June-November). After removing the preceding ACE signal (Fig. 8b), the eastward propagation distance of the equatorial Kelvin wave shortens significantly; indeed, after June of an EP El Niño developing year, the propagating characteristics of Kelvin wave have largely disappeared. This is related to the role of the WNP TCs in the TC season. The center of thermocline depth anomalies over the eastern Pacific shifts to $150^{\circ} \mathrm{E}-180^{\circ}$, and the anomalous thermocline depth reaches its maximum before May. After removing the influence of SST anomalies in the Niño-3.4 region (Fig. 8c) or tropical western Pacific (Fig. 8d), the modulation of the preceding WNP ACE on propagation of Kelvin waves is still evident. For CP El Niño (Fig. 8e-h), removing the preceding ACE signal seems to have little impact on the spatial evolution of the zonal thermocline depth.

Next, the influence of the WNP TCs on Kelvin wave propagation during the two types of El Niño is assessed. When the WNP ACE anomalies are positive, the eastward propagation speed of Kelvin waves is proportional to the ACE strength; when the ACE anomalies are negative, WNP TCs have no evident influence on the eastward propagation speed of Kelvin waves (Fig. 9). To further verify this result, we consider the spatial evolution of the zonal thermocline depth anomalies during four CP El Niño events in which ACE anomalies are positive (Fig. 10a, b): After removing the preceding WNP ACE, the eastward propagation of the Kelvin wave is much weaker, the anomalous thermocline depth still reaches its maximum before May. After removing the influence of SST anomalies in the Niño-3.4 region (Fig. 10c) or tropical western Pacific (Fig. 10d), the modulation of the preceding WNP ACE on propagation of Kelvin waves weakens, but it still exists. Hence, under the condition of positive ACE anomalies, when the preceding WNP ACE is stronger, Kelvin waves propagate farther east and the center of SST anomalies is farther east, supporting the occurrence of an EP El Niño spatial pattern. When the preceding WNP ACE is weaker, Kelvin waves do not propagate so far eastwards, supporting the development of the $\mathrm{CP} \mathrm{El}$ Niño spatial pattern.

In addition to the above path, the change in thermocline depth may be linked to Ekman pumping resulting from the anomalous Walker circulation related to TCs. During EP El Niño (Fig. 11a), because of the Ekman pumping, the center of the deepened thermocline depth anomalies is consistent with the center of low-pressure anomalies related 


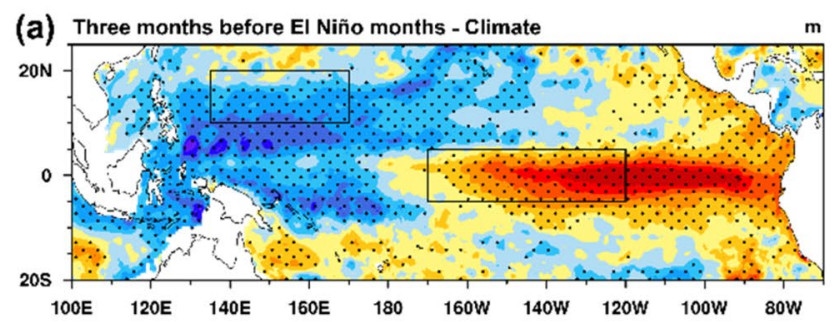

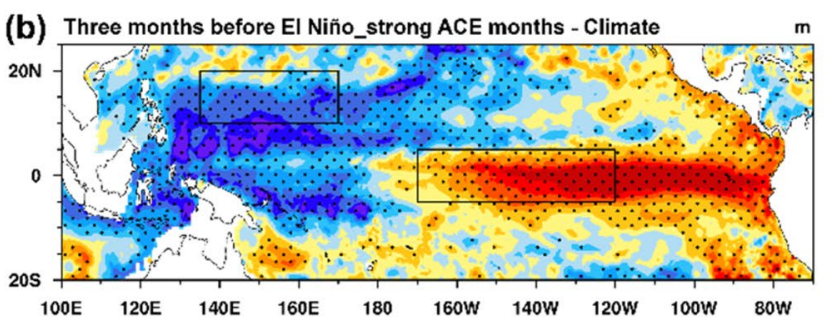

(d) Three months before EI Niño_strong ACE months - Three months

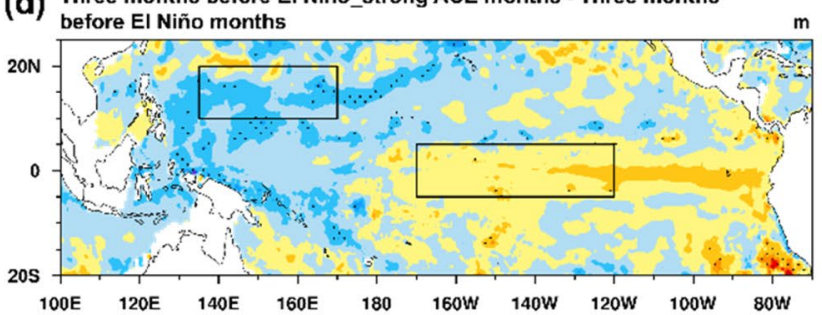

(f) Three months before EI Niño_strong ACE months - Three months (f) before El Niño months

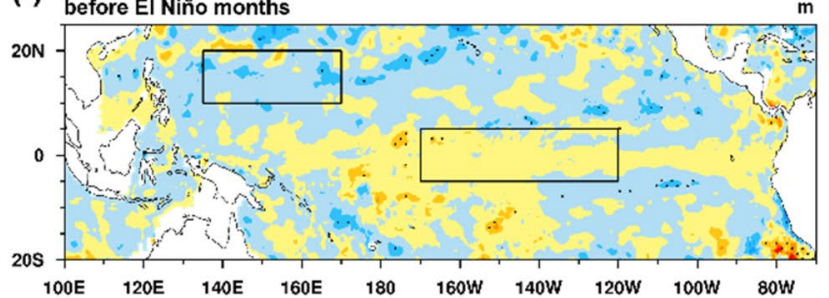

(h) Three months before EI Niño_strong ACE months - Three months
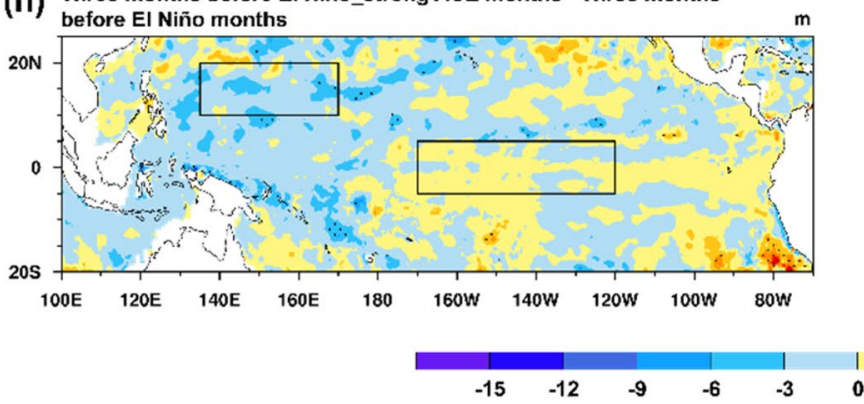

Fig. 6 Composite of the anomalous depth of the thermocline $\left(20{ }^{\circ} \mathrm{C}\right.$ isotherm, shading, m). a Composite of the anomalous depth of the $20{ }^{\circ} \mathrm{C}$ isotherm 3 months before El Niño months. The stippled regions denote statistical significance above the 95\% confidence level (Student's $t$-test). The black rectangles denote the key ACE region $\left(10^{\circ}-20^{\circ} \mathrm{N}, 135^{\circ}-170^{\circ} \mathrm{E}\right)$ and the Niño-3.4 region $\left(5^{\circ} \mathrm{S}-5^{\circ}\right.$ $\left.\mathrm{N}, 120^{\circ}-170^{\circ} \mathrm{W}\right)$. b As in (a), but for El Niño_strong ACE case. c As in (a), but for El Niño_weak ACE case. d Composite difference (c) Three months before El Niño_weak ACE months - Climate

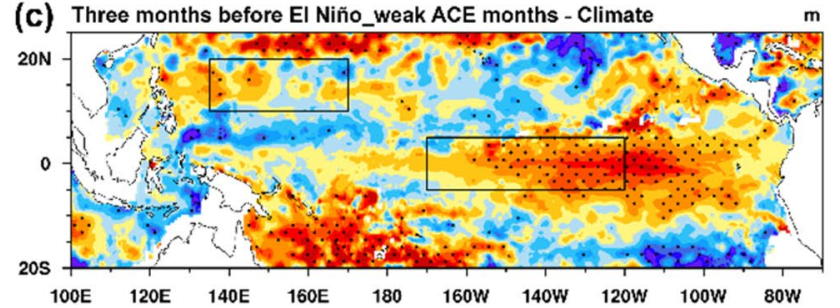

(e) Three months before EI Niño_weak ACE months - Three months

(e) before El Niño months

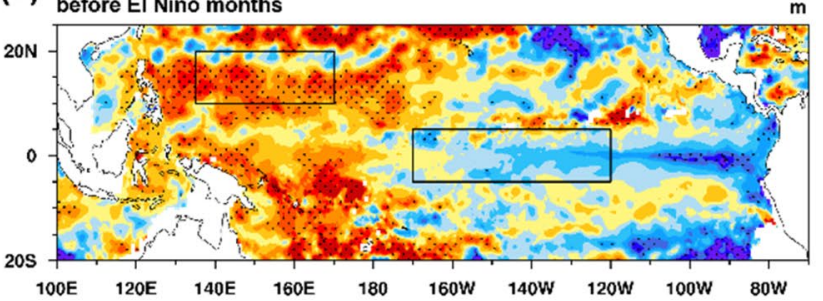

(g) Three months before EI Niño_weak ACE months - Three months
before EI Niño months

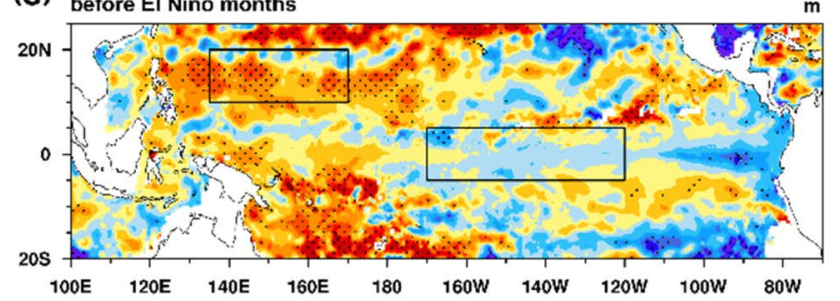

(i) Three months before EI Niño_weak ACE months - Three months

(i) before EI Niño months

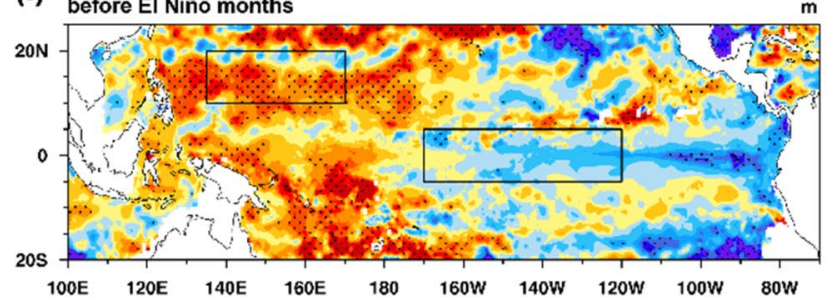

\begin{tabular}{lllll}
\hline & 6 & 9 & 12 & 15
\end{tabular}

in the preceding anomalous depth of the $20{ }^{\circ} \mathrm{C}$ isotherm between $\mathrm{El}$ Niño_strong ACE and El Niño months. e As in (d), but for El Niño_ weak ACE and El Niño months. $\mathbf{f}-\mathbf{g}$ As in $(\mathbf{d}, \mathbf{e})$, but the preceding anomalous depth of the $20{ }^{\circ} \mathrm{C}$ isotherms are those after removing the influence of the Niño-3.4 index. $\mathbf{h}-\mathbf{i}$ As in (d, e), but for those after removing the influence of SST anomalies in the tropical western Pacific $\left(10^{\circ} \mathrm{S}-10^{\circ} \mathrm{N}, 120^{\circ}-160^{\circ} \mathrm{E}\right)$ 


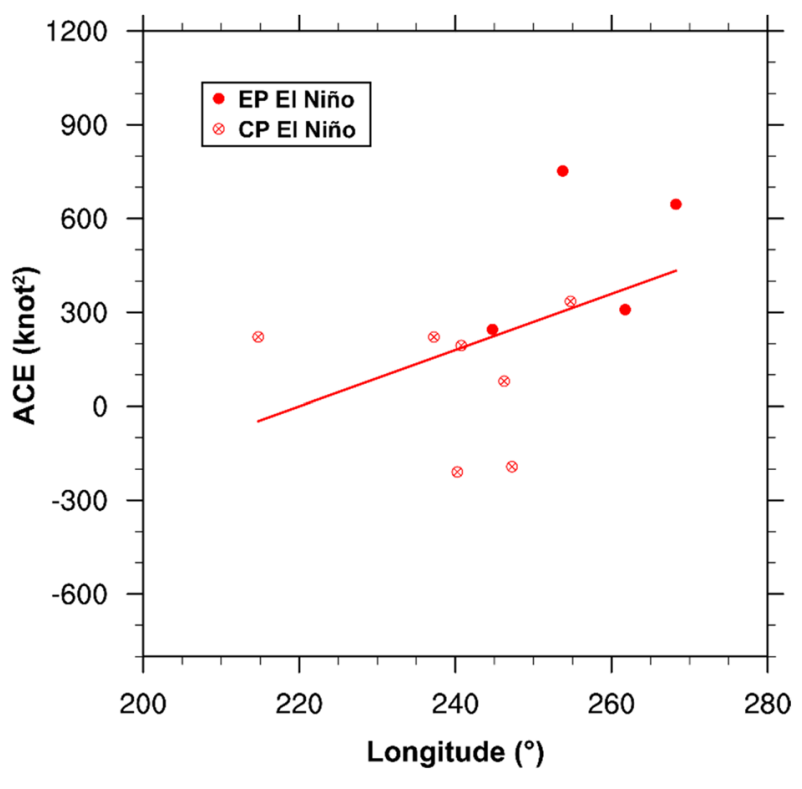

Fig. 7 Scatter diagram of the WNP ACE anomalies $\left(\mathrm{knot}^{2}\right)$ against the longitude of the maximum zonal thermocline $\left(20{ }^{\circ} \mathrm{C}\right.$ isotherm) depth anomalies over the equatorial eastern Pacific $\left(5^{\circ} \mathrm{S}-5^{\circ} \mathrm{N}, 80^{\circ}\right.$ $\mathrm{W}-180^{\circ}$ ) during El Niño events in the period 1970-2010. The red dots and red dots with a cross represent EP El Niño and CP El Niño, respectively. Here, $200^{\circ}$ indicates $160^{\circ} \mathrm{W}$, and $280^{\circ}$ indicates $80^{\circ} \mathrm{W}$. And ACE are the sum of ACE during the El Niño developing year. And longitude of the maximum zonal thermocline depth is selected from November in the developing year to the following January

to the anomalous Walker circulation. After removing the effect of the preceding WNP ACE (Fig. 11b), low-pressure anomalies over the eastern Pacific related to the anomalous Walker circulation are weakened, which means the Ekman pumping is weakened, and the thermocline over the eastern Pacific does not deepen so much. Meantime, the spatial pattern clearly changes, especially after May. Negative pressure anomalies expand westward before November, so that the thermocline shallowing depth over the western Pacific is less marked. Thus, the development of EP El Niño is suppressed after removing the preceding WNP ACE. The modulation of the preceding WNP ACE on Ekman pumping shows little dependency on the local SST anomalies (Fig. 11c, d). During CP El Niño (Fig. 11e-h), the change in thermocline depth anomalies also follows the change in sea surface pressure anomalies related to the preceding WNP TCs.

Finally, the lead-lag correlation between the ACE anomalies and the zonal thermocline gradient further verifies that the modulation of the thermocline by the WNP TCs reaches its peak after 3 months, and this relationship is independent of the autocorrelation of the zonal thermocline gradient (Fig. 12).

\section{An improved model (ACE + SST model) is employed to predict El Niño diversity}

Based on the characteristics (Wang and Li 2022) and possible mechanisms that the WNP TCs modulate El Niño diversity, a modified empirical model (ACE + SST model) is constructed to verify the role of the WNP TCs in El Niño diversity.

\subsection{Predictions for Niño-3 and Niño-4}

Firstly, the ACE + SST model is employed to predict SST anomalies in the key Niño-3 and Niño-4 domains that correspond to the anomalous SST centers during EP and CP El Niño events, respectively (Fig. 13). The correlation coefficient between the observed Niño-3 and that predicted by the ACE + SST model can reach $\sim 0.89$, much higher than for the single-factor SST model ( 0.69) and the ACE model $(\sim 0.62)$. The root mean square error (RMSE) between the observed Niño-3 and that predicted by the ACE + N3.4 model is $\sim 0.41{ }^{\circ} \mathrm{C}$, which is smaller than that for the SST model $\left(\sim 0.57{ }^{\circ} \mathrm{C}\right)$ and the ACE model $\left(\sim 0.65^{\circ} \mathrm{C}\right)$. For the Niño-4 index, the correlation coefficient between the observed Niño- 4 and that predicted by the ACE + N3.4 model can reach $\sim 0.92$, much higher than for the singlefactor SST model $(\sim 0.82)$ and ACE model $(\sim 0.56)$. The RMSE between the observed Niño-4 and that predicted by the ACE $+\mathrm{N} 3.4$ model is $\sim 0.29^{\circ} \mathrm{C}$, which is smaller than that for the SST model $\left(\sim 0.39^{\circ} \mathrm{C}\right)$ and the ACE model $\left(\sim 0.64{ }^{\circ} \mathrm{C}\right)$. Compared with the SST model, the predictions by the ACE model have a lower correlation coefficient and higher RMSE with respect to observations, but the peak Niño indices obtained with the SST model occurs 3 months after the peak in the observations, while the predictions by the ACE model peak at the same time as the observations. Moreover, the ACE can reduce the influence of SST persistence during the decaying period in the El Niño year, further leading to the sharply decreasing SST anomalies during the decaying period of El Niño. Thus, ACE is verified to have an important role in the prediction of the two indices, especially phase-locking of the peak of El Niño events and the sharp decrease in SST anomalies during the decaying period of El Niño.

\subsection{Comparison of the predicted skill for El Niño diversity among the ACE + SST model and the state-of-art models}

To compare the skill in predicting El Niño diversity of the ACE + SST model with the current models, the predictions for Niño-3.4 index during the two types of El Niño from the ACE + SST model, 18 dynamical models, and 8 

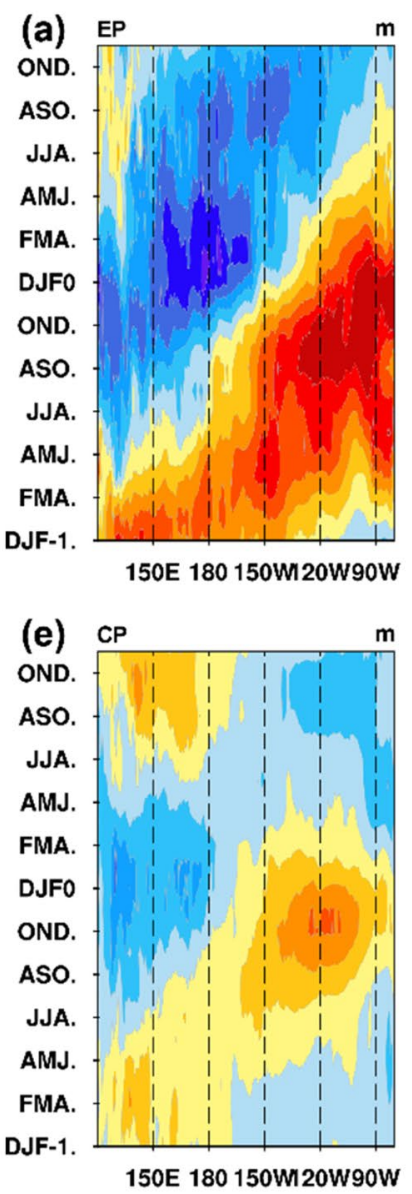
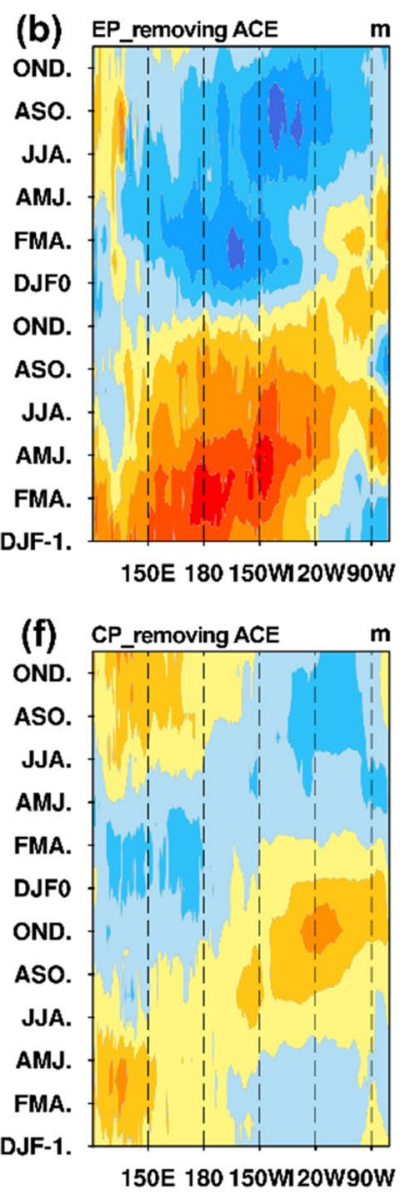

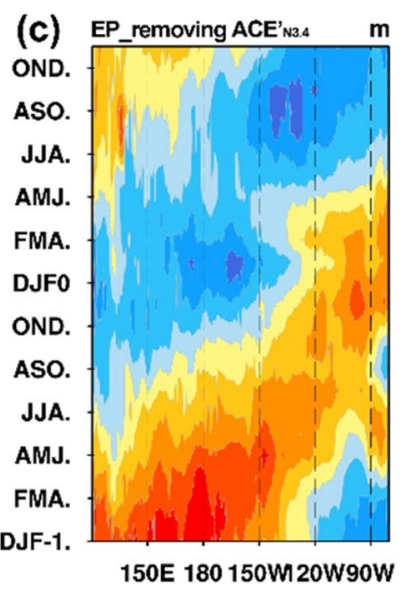

(g) CP_removing ACE' ${ }^{2} 4$ m

OND.

ASO.

JJA.

AMJ

FMA.

DJF0

OND.

ASO.

JJA.

AMJ.

FMA.

DJF-1.

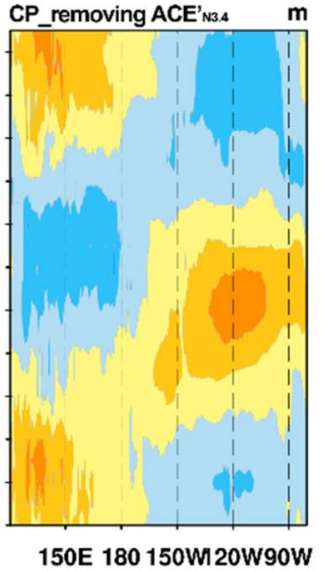

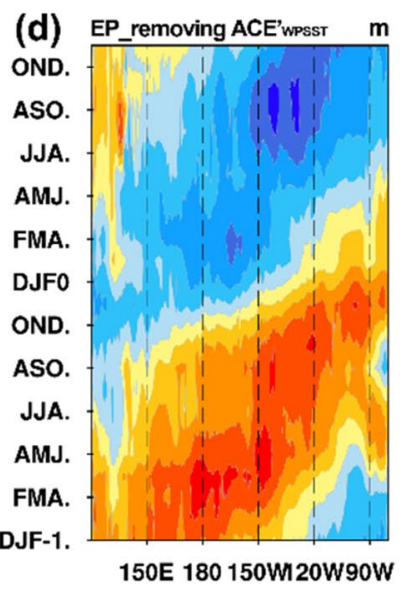

(h) CP removing ACE'

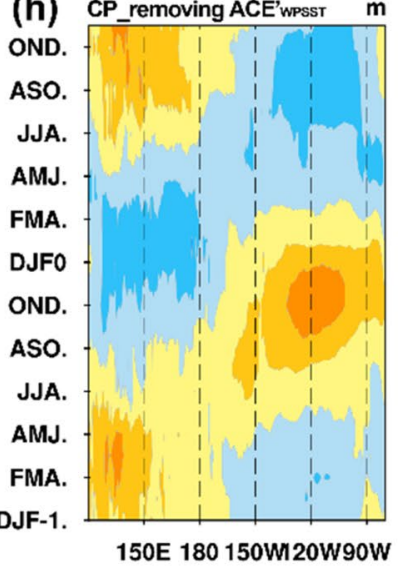

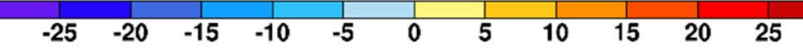

Fig. 8 Spatial evolution of zonal thermocline depth (along $5^{\circ} \mathrm{S}-5^{\circ}$ $\mathrm{N}$, shading, $\mathrm{m}$ ) anomalies during EP and CP El Niño in the period 1970-2010. a Composite of zonal thermocline depth anomalies during EP El Niño. DJF-1 and DJF0 represent the December-February of the previous year and the year when the peak of El Niño occurs, respectively. b As in (a), but for the zonal thermocline depth anoma- lies removing the effect of the preceding WNP ACE anomalies. $\mathbf{c}$ As in (b), but for the preceding WNP ACE anomalies after removing the Niño-3.4 index. $\mathbf{d}$ As in (b), but for the preceding WNP ACE anomalies after removing the SST anomalies in the tropical western Pacific $\left(10^{\circ} \mathrm{S}-10^{\circ} \mathrm{N}, 120^{\circ}-160^{\circ} \mathrm{E}\right)$. $\mathbf{e}-\mathbf{h}$ As in $(\mathbf{a}-\mathbf{d})$, but for CP El Niño events

Niño-3.4 index 3 months after the active WNP TC season (June-November) for both EP and CP El Niño.

\subsection{The ACE + SST model can predict well the spatial pattern of EI Niño}

Except for examining the predicted skill of the ACE + SST model for the various of indices during different El Niño events, this paper further explores the model's predicted skill for El Niño spatial distribution and evolution. The predicted results indicate the $\mathrm{ACE}+\mathrm{SST}$ model can reproduce well the spatial intensity and distribution of El Niño event (figure is not shown). Below, the predicted results from the ACE + SST model for the El Niño diversity are shown.

Figure 15 shows the zonal distribution of tropical SST anomalies in the hindcasting period. The predicted center 


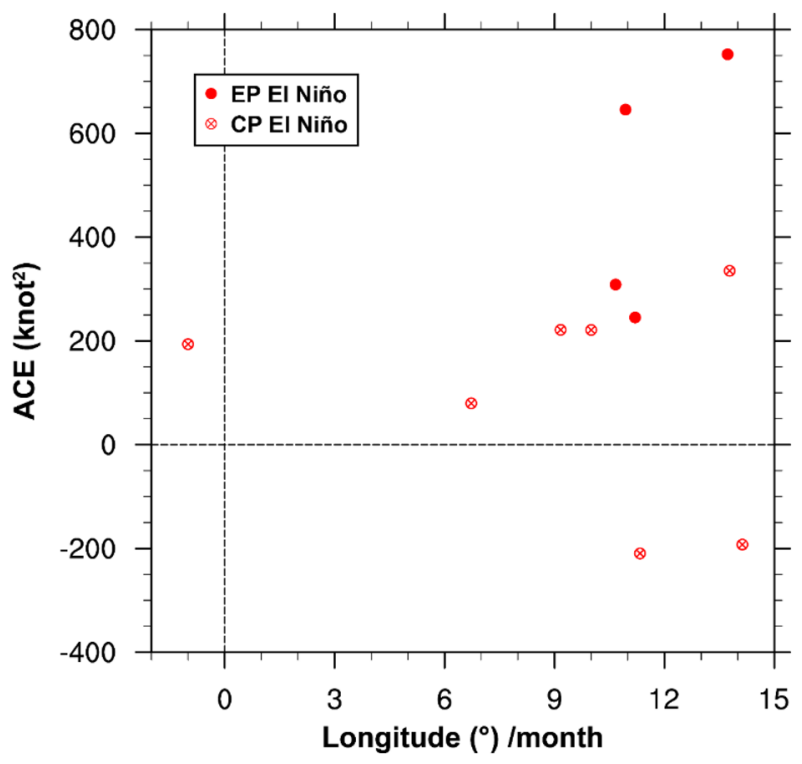

Fig. 9 Scatter diagram of the WNP ACE anomalies plotted against the eastward propagation speed of Kelvin waves during EP and CP El Niño. Red dots represent EP El Niño and red dots with a cross represent CP El Niño

of maximum SST anomalies by the ACE + SST model is almost coincident with observations regardless of EP and CP El Niño events, except for the slight eastward shift of the SST anomaly center during EP El Niño event. The ACE + SST model shows an excellent prediction skill for the spatial patterns of EP and CP El Niño (Fig. 16), as attested by the statistical results. The spatial similarity between the observed and predicted SST anomalies $\left(5^{\circ} \mathrm{S}-5^{\circ} \mathrm{N}, 160^{\circ}\right.$ E-90 ${ }^{\circ} \mathrm{W}$ ) from November to January during EP (CP) El Niño can reach $\sim 0.976(\sim 0.932)$, with RMSE of $\sim 0.229{ }^{\circ} \mathrm{C}$ $\left(\sim 0.171^{\circ} \mathrm{C}\right)$ and sign consistency rate of $\sim 99.6 \%$ for both types. Over a larger meridional extent $\left(35^{\circ} \mathrm{S}-35^{\circ} \mathrm{N}\right)$, the spatial similarity between the observed and predicted SST during EP (CP) El Niño can also reach 0.931 ( 0.909), the RMSE $\sim 0.320{ }^{\circ} \mathrm{C}\left(\sim 0.186{ }^{\circ} \mathrm{C}\right)$, and the sign consistency rate $\sim 90 \%(\sim 82.09 \%)$. In addition, the ACE + SST model captures well the characteristics of El Niño evolution, regardless of El Niño type, except for the slight eastward extension of the SST anomaly center during CP El Niño events (Fig. 17).

\subsection{Robustness of the ACE + SST model}

Although the ACE + SST model shows its excellent predicted skill for El Niño spatial pattern, it is necessary to check its robustness. Sometimes, model's predicted skill might depend on its training period. Figure 18a shows the spatial correlation coefficient and RMSE between the observed and predicted SST anomaly (over the region $5^{\circ}$
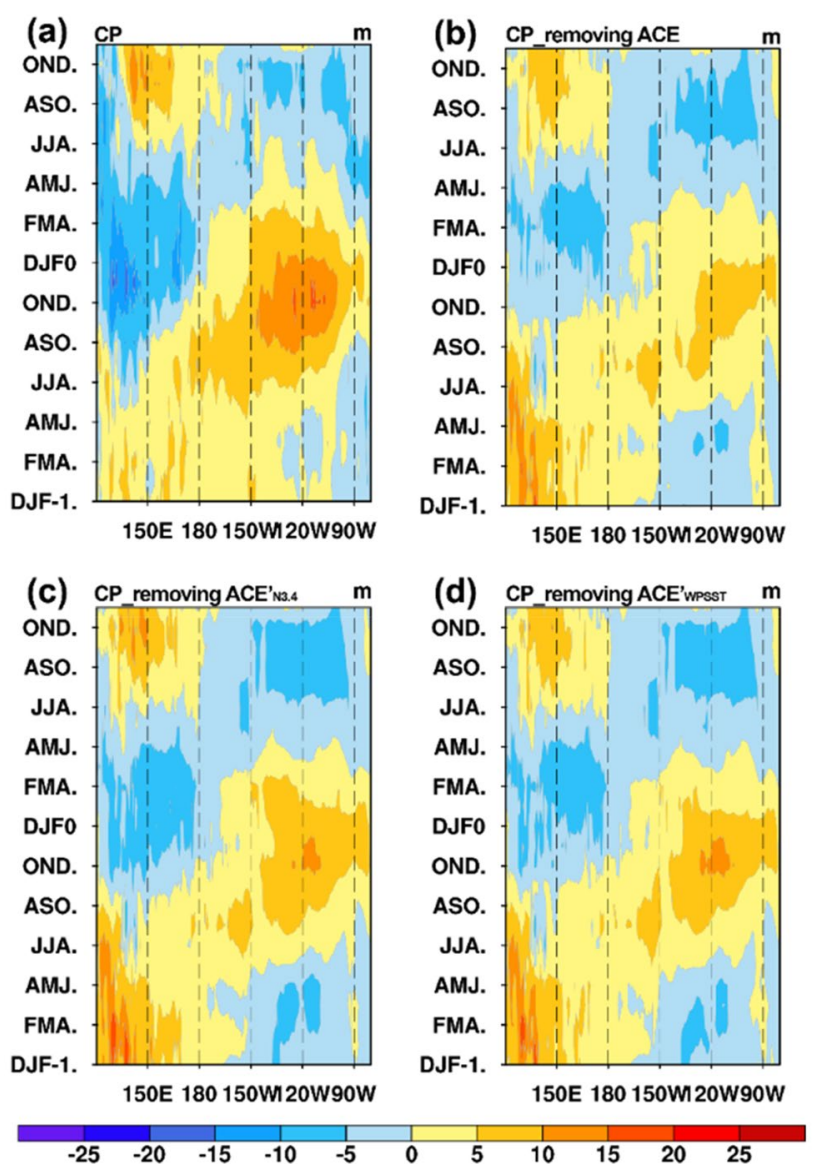

Fig. 10 As in Fig. 8, but for CP El Niño events when ACE anomalies are positive and there is the eastward propagation of Kelvin wave

$\mathrm{S}-5^{\circ} \mathrm{N} 160^{\circ} \mathrm{E}-90^{\circ} \mathrm{W}$ ) from the ACE $+\mathrm{SST}$ model as a function of hindcast time. The results indicate that the predicted ability of the ACE + SST model does not depend on the selection of the training period; the mean correlation coefficient between predicted and observed SST anomalies is $\sim 0.97$ and the mean RMSE is $\sim 0.02{ }^{\circ} \mathrm{C}$. At a larger scale $\left(35^{\circ} \mathrm{S}-35^{\circ} \mathrm{N}, 160^{\circ} \mathrm{E}-90^{\circ} \mathrm{W}\right)$, the results are similar (Fig. 18b); the mean correlation coefficient between predicted and observed SST anomalies is $\sim 0.95$ and the mean RMSE is $\sim 0.03{ }^{\circ} \mathrm{C}$. The RMSE is small because the average SST anomalies from 1970 to 2018 are small in each grid cell (in the modelling method, the period from 1970.01 to 1999.12 is defined as the base period; the anomalies of SST and ACE in the model are calculated relative to this base period.). The high spatial correlation coefficient and low RMSE between the observation and prediction indicate that the ACE + SST model is robust.

Figure 19 shows the average correlation coefficient and RMSE between the observed and predicted SST anomaly $\left(5^{\circ}\right.$ $\mathrm{S}-5^{\circ} \mathrm{N}, 160^{\circ} \mathrm{E}-90^{\circ} \mathrm{W}$ ) from the ACE $+\mathrm{SST}$ model at each grid cell using the method of Leave-P-out Cross-Validation. 

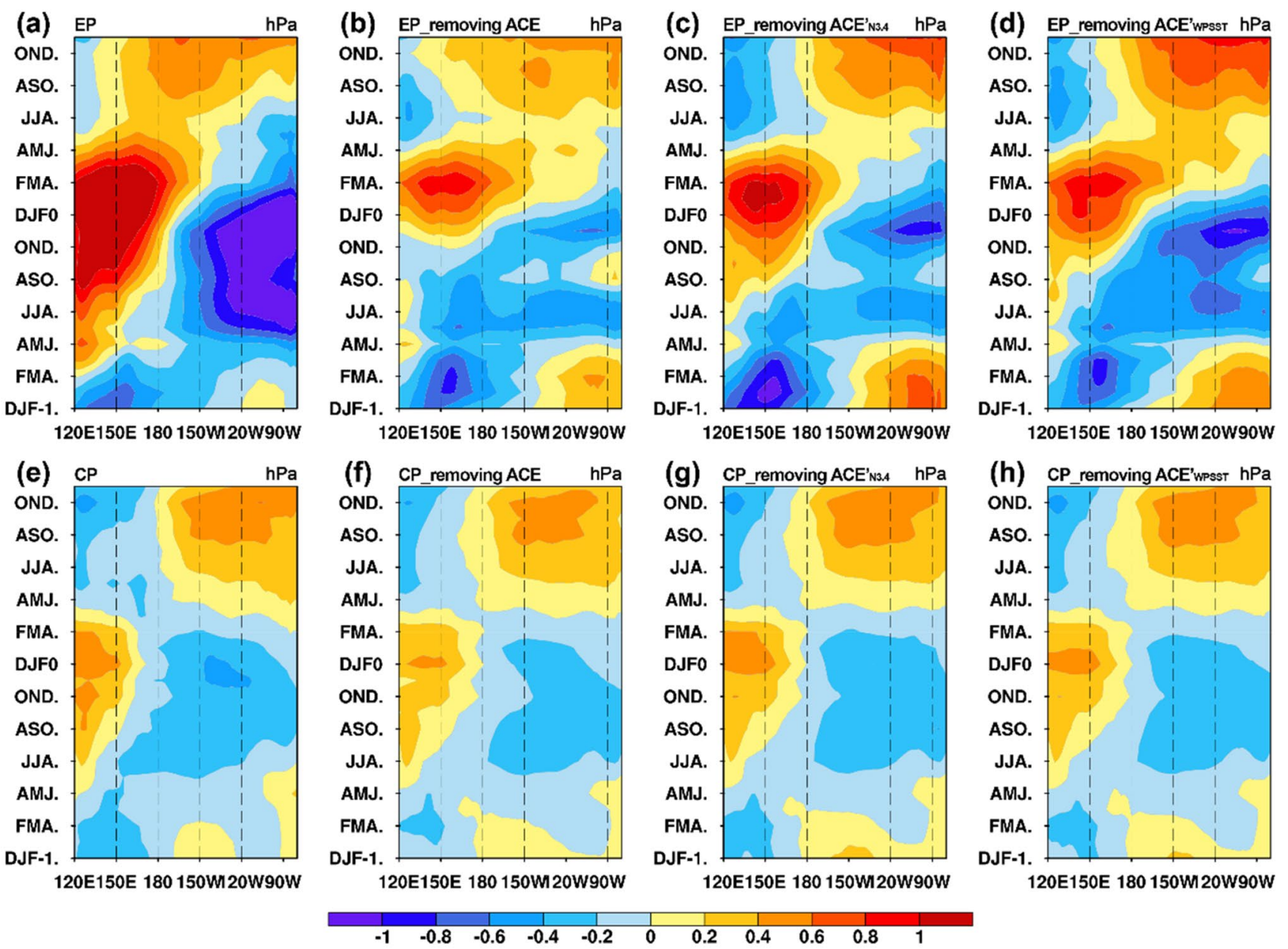

Fig. 11 As in Fig. 8, but for the spatial evolution of sea level pressure (along $5^{\circ} \mathrm{S}-5^{\circ} \mathrm{N}, \mathrm{hPa}$ ) anomalies during EP and CP El Niño events in the period 1970-2018

There is a high correlation coefficient and low RMSE between observation and prediction in each grid cell. The mean correlation coefficient over all grid cells is $\sim 0.90$ and the mean RMSE $\sim 0.37{ }^{\circ} \mathrm{C}$. This indicates that the $\mathrm{ACE}+\mathrm{SST}$ model has good prediction skill in each grid cell, and the ACE + SST model is robust in each grid cell. The spatial distribution of RMSE between observation and prediction shows that the RMSE increases moving eastward. This is because the influence of the WNP TCs on SST decreases slightly from the western to eastern Pacific, which further verifies the role of the WNP ACE in the ACE + SST model.

\section{Summary and discussion}

Part I of this study has shown an important feedback of TCs over the WNP on the El Niño diversity (Wang and Li 2022). In this Part, we further explore the possible mechanisms on this feedback. WNP TCs could affect El Niño diversity by atmospheric and oceanic bridges: As shown in Fig. 20, compared with the El Niño months, when El Niño events are preceded by strong ACE, the Walker circulation is weakened and the east-west thermocline gradient is reduced. Then, warm sea water over the western Pacific is transferred to farther east, and the center of maximum positive SST anomalies is located in the equatorial eastern Pacific, which helps the development of the EP El Niño event. In contrast, when El Niño events are preceded by weak ACE, compared with El Niño months, the Walker circulation is enhanced and the east-west thermocline gradient is strengthened. Thus, the eastward transport of warm sea water from the western Pacific is suppressed, and the center of maximum positive SST anomalies is limited to the equatorial central Pacific, which helps the development of CP El Niño. The modulation of thermocline depth by the WNP TCs mainly results from Kelvin wave propagation and Ekman pumping during the EP and CP El Niño events, and Kelvin wave propagation works 


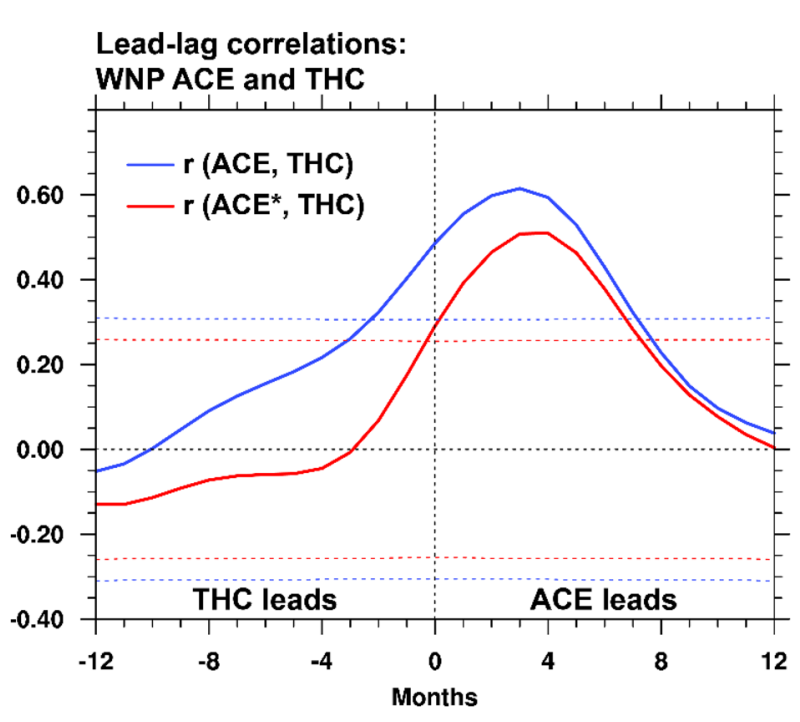

Fig. 12 Lead-lag correlations between the WNP ACE anomalies and zonal thermocline gradient $\left(20^{\circ} \mathrm{C}\right.$ isotherm $\operatorname{depth}_{\left[5^{\circ} \mathrm{S}-5^{\circ} \mathrm{N}, 120^{\circ}-170^{\circ} \mathrm{W}\right]}$ $-20{ }^{\circ} \mathrm{C}$ isotherm depth ${ }_{\left[5^{\circ} \mathrm{S}-5^{\circ} \mathrm{N}, 120^{\circ}-170^{\circ} \mathrm{E}\right]}$ ) over the period $1970-$ 2010. ACE* indicates the WNP ACE index that is not associated with the preceding thermocline. The blue and red dashed lines indicate the 99\% confidence levels related to lead-lag correlations between thermocline and ACE, and thermocline and ACE*, respectively, via Student's $t$-test using the effective number of degrees of freedom

in parts of CP El Niño events. When the ACE anomalies are positive, the eastward propagation speed of Kelvin wave is proportional to the ACE strength, whereas when the ACE anomalies are negative, the WNP TCs have no evident influence on the eastward propagation speed. Furthermore, the
SST anomalies in the Niño-3.4 region and tropical western Pacific play small roles in the atmospheric and oceanic processes that WNP TCs affect El Niño diversity.

A modified physically based empirical model, ACE + SST model, for predicting El Niño diversity is further constructed based on the preceding WNP ACE and SST. And the predicted skill of this model is examined by predicting the various of indices and spatial pattern related to El Niño diversity. Results indicate the ACE + SST model can predict well the spatial structure and evolution of El Niño. This new model shows its some advantages over the current dynamical and statistical models in the indices prediction. WNP TCs are verified to play an important role in the prediction of the phase-locking of the peak of El Niño events and the sharp decrease in SST anomalies during the decaying period of two types of El Niño. Furthermore, the predicted skill of the ACE + SST model does not depend on the training period selected. These predictions of the ACE + SST model provide the powerful evidence that the WNP TCs are essential to the El Niño diversity.

Although this study proposes two pathways that the WNP TCs modulate El Niño diversity and discusses preliminarily the role of local SST in these two pathways, it is necessary to further verify the influence of local SST and other factors on the causality associated with the influence of the WNP TCs on atmospheric circulation and thermocline in a fully coupled model. And which pathway is more important or whether they couple together (i.e., whether there is a coupled oceanic-atmospheric bridge) is still an unsolved issue. The slight eastward extension of predicted
Fig. 13 Time series of Niño index $\left({ }^{\circ} \mathrm{C}\right)$ from observations and predictions by models in the period 2000-2018. a Time series of the Niño-3 index for all months. The two horizontal black dashed lines indicate $0.5^{\circ} \mathrm{C}$ and $-0.5^{\circ} \mathrm{C}$. The black solid line indicates observations. The red, blue and turquoise solid lines are the predictions from the ACE + SST, SST and ACE models, respectively. $r$ is the correlation coefficient between observations and predictions. $\mathbf{b}$ As in (a), but for the Niño-4 index (a)

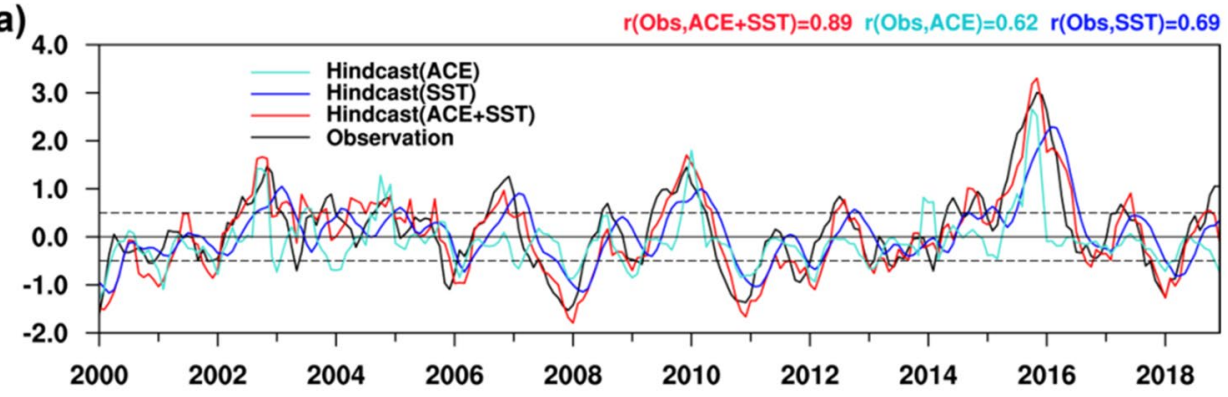

(b)

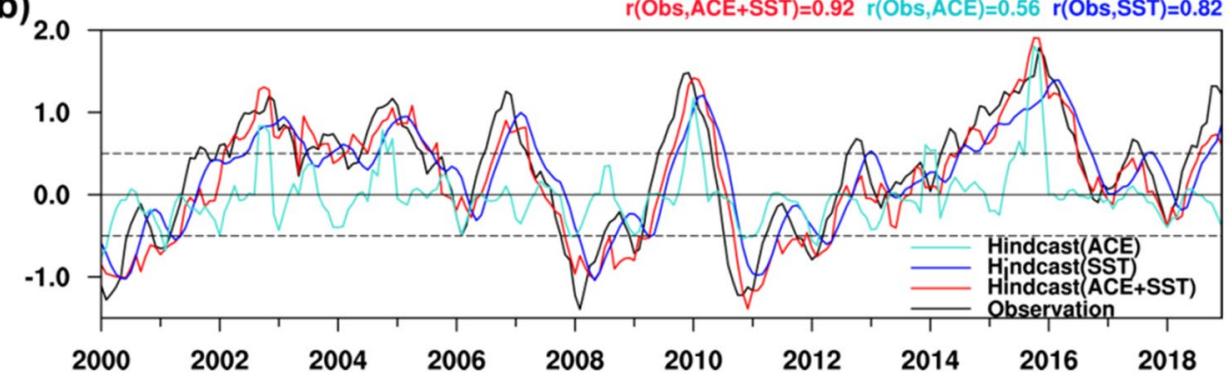



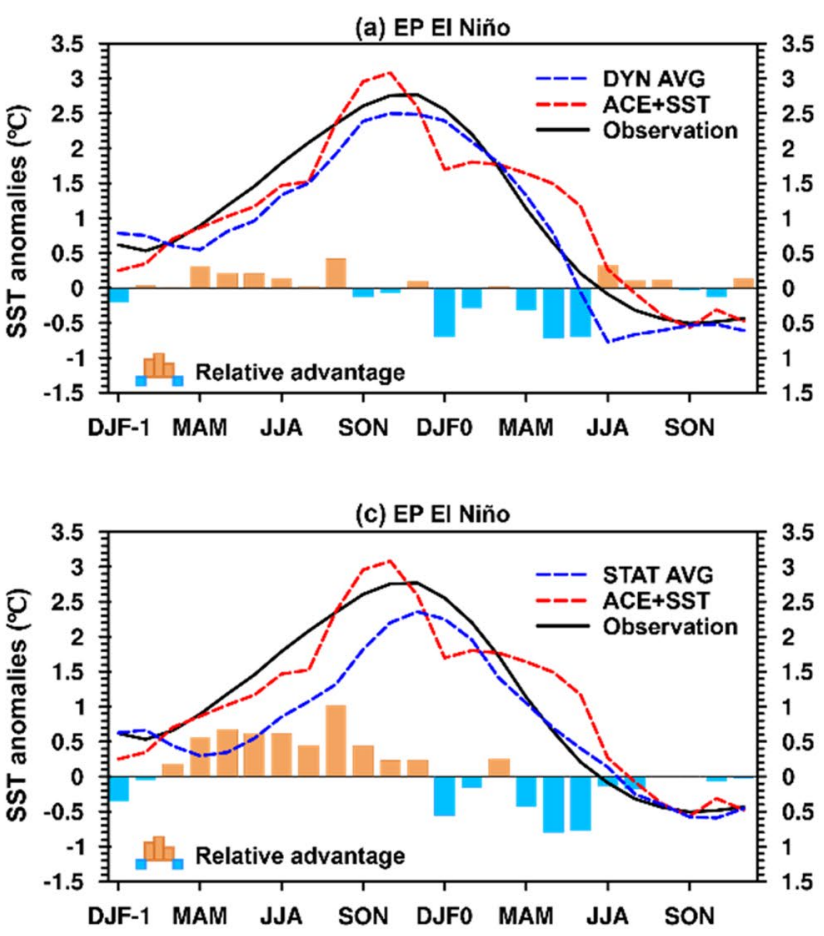

Fig. 14 Composite time series of Niño-3.4 index $\left({ }^{\circ} \mathrm{C}\right)$ for observations and predictions of $\mathrm{El}$ Niño events in the hindcasting period (2002-2018). a Composite time series of Niño-3.4 index for EP El Niño events. Blue dashed line is the average prediction by dynamical models, and red dashed line is that for the ACE+SST model. Black solid line is observations. Bars indicate the amplitude of the models' relative advantage (relative advantage ${ }_{\text {model } \mathrm{A} \rightarrow \text { model } \mathrm{B}}=\mid$ Model $\mathrm{A}-$ Observation $|-|$ Model B

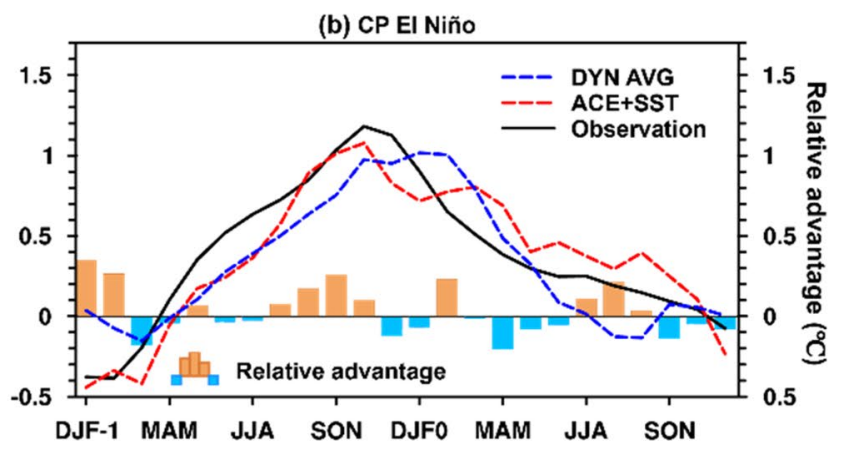

(d) CP EI Niño

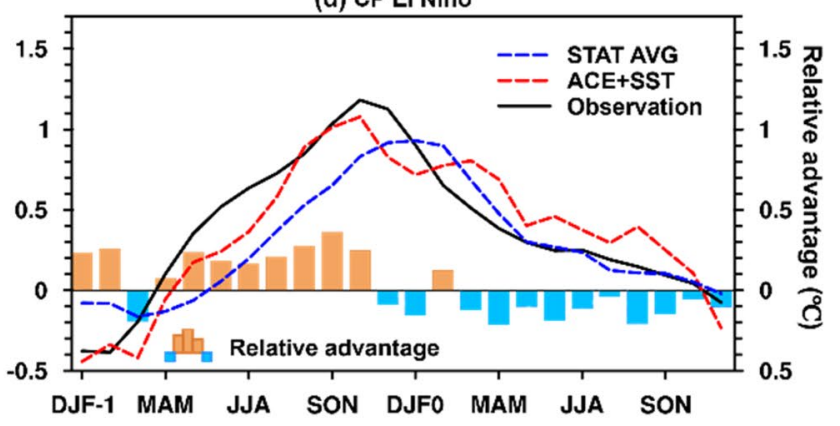

between the average of the dynamical models and the ACE + SST model. Blue bars indicate that the dynamical model average performs better than the ACE + SST model, while orange bars indicate that the ACE + SST model performs better. DJF-1 and DJF0 represent December-February in the previous year and the year of peak El Niño, respectively. b As in (a), but for CP El Niño events. $\mathbf{c}, \mathbf{d}$, As in (a, b), but for statistical models

- Observationl)
SST anomalies center during CP El Niño is still an unresolved issue, which indicates that the ACE + SST model needs further be improved. Meanwhile, El Niño diversity has other important impact factors (Hu et al. 2012; Ding et al. 2019), which still need to be taken into consideration in the future model improvement. Furthermore, how to add the influence of TCs to the state-of-art dynamical models for El Niño is still a huge challenge. Overall, this study is a good reminder that TC activity might be an important stochastic forcing to El Niño (Keen 1982; Lian et al. 2018; Wang et al. 2019b) and this climatic effect of TCs deserves more studies.

\section{Appendix 1}

As mentioned in the method, the ACE + SST model in this paper is the improved version of the ACE $+\mathrm{N} 3.4$ model (Wang et al. 2019b). The basis of the ACE+SST model is Running Holdout Method.

\section{- Running Holdout Method}

In this method, the whole time series is divided into two periods, the training period and the hindcasting period. And the training period is a variable-length period that changes with the hindcasting time point. In this study, the base period is selected as the shortest training period.

The real predictor variables used in this study are the standardized accumulated cyclone energy (ACE) anomalies 


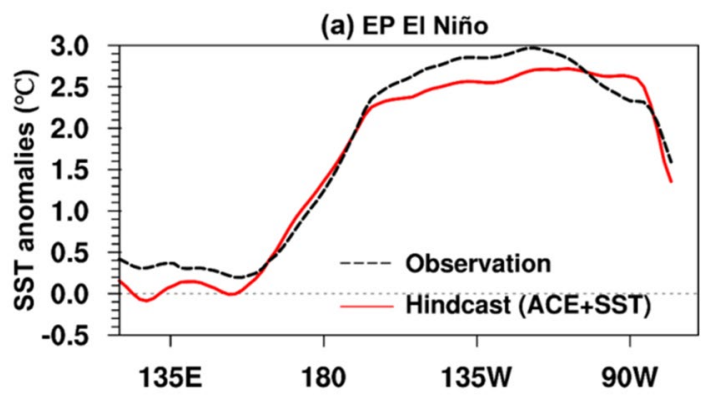

(b) CP EI Niño

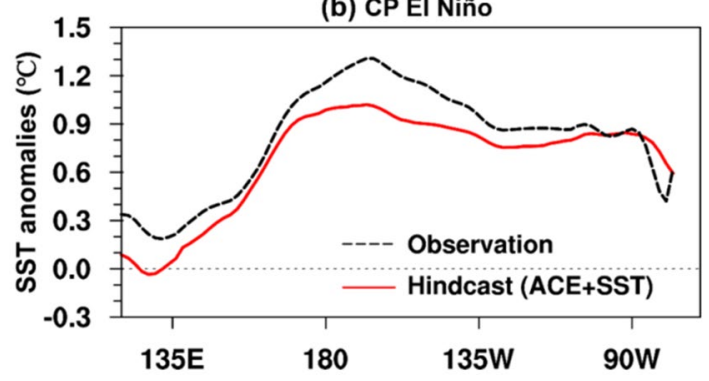

Fig. 15 Zonal distribution of the observed and predicted SST anomalies $\left({ }^{\circ} \mathrm{C}\right)$ along $5^{\circ} \mathrm{S}-5^{\circ} \mathrm{N}$ from November to January in the period 2000-2018. a SST anomalies during EP El Niño. Black dashed line indicates observations and red line indicates the prediction from the ACE + SST model. b As in (a), but for CP El Niño
$\left(\mathrm{ACE}^{*}\right)$ and standardized sea surface temperature (SST) anomalies (SST*) at each grid 3 months earlier, and the dependent variable is SST anomaly at each grid. Previous study (Wang et al. 2019b) has pointed the key domains of the preceding ( 3 months earlier) ACE in different ENSO events have some distinctions: During an El Niño event, the ACE over the $10^{\circ}-20^{\circ} \mathrm{N}, 135^{\circ}-170^{\circ} \mathrm{E}$ plays an important role in the development of Niño-3.4 index, and $10^{\circ}-25^{\circ}$ $\mathrm{N}, 130^{\circ}-155^{\circ} \mathrm{E}$ for a La Niña event. To other periods, we choose a common domain of $10^{\circ}-20^{\circ} \mathrm{N}, 135^{\circ}-155^{\circ} \mathrm{E}$ to build the new model. And according to the definition of ENSO event, these three areas are distinguished by the $0.5^{\circ} \mathrm{C}$ anomaly of the preceding Niño-3.4 index. Thus, single ACE model consists of three parts:

$$
\begin{array}{ll}
S S T_{i}=c_{1} A C E_{i-3}^{*}+g_{1}, & N 3.4_{i-3} \geq 0.5, A C E\left(10^{\circ}-20^{\circ} N, 135^{\circ}-170^{\circ} E\right) \\
S S T_{i}=c_{2} A C E_{i-3}^{*}+g_{2}, & \left|N 3.4_{i-3}\right|<0.5, A C E\left(10^{\circ}-20^{\circ} N, 135^{\circ}-155^{\circ} E\right) \\
S S T_{i}=c_{3} A C E_{i-3}^{*}+g_{3}, & N 3.4_{i-3} \leq-0.5, A C E\left(10^{\circ}-25^{\circ} N, 130^{\circ}-155^{\circ} E\right)
\end{array}
$$

where $\mathrm{SST}_{\mathrm{i}}$ is SST anomaly at the $i$ th month, N3.4 ${ }_{\mathrm{i}-3}$ is Niño-3.4 index at the (i-3)th month, $\mathrm{ACE}^{*}{ }_{\mathrm{i}-3}$ the standardized ACE anomalies at the (i-3)th month, and $\mathrm{c}_{1}, \mathrm{c}_{2}, \mathrm{c}_{3}$ and $\mathrm{g}_{1}, \mathrm{~g}_{2}, \mathrm{~g}_{3}$ are the regression coefficients and constants. To SST model, $\mathrm{ACE}^{*}{ }_{\mathrm{i}-3}$ is replaced by SST*. Similarly, three parts of ACE + SST model are built, as follows:

$$
\begin{cases}S S T_{i}=c_{4} A C E_{i-3}^{*}+d_{1} S S T_{i-3}^{*}+g_{4}, & N 3.4_{i-3} \geq 0.5, A C E\left(10^{\circ}-20^{\circ} N, 135^{\circ}-170^{\circ} E\right) \\ S S T_{i}=c_{5} A C E_{i-3}^{*}+d_{2} S S T_{i-3}^{*}+g_{5}, & \left|N 3.4_{i-3}\right|<0.5, A C E\left(10^{\circ}-20^{\circ} N, 135^{\circ}-155^{\circ} E\right) \\ S S T_{i}=c_{6} A C E_{i-3}^{*}+d_{3} S S T_{i-3}^{*}+g_{6}, & N 3.4_{i-3} \leq-0.5, A C E\left(10^{\circ}-25^{\circ} N, 130^{\circ}-155^{\circ} E\right)\end{cases}
$$
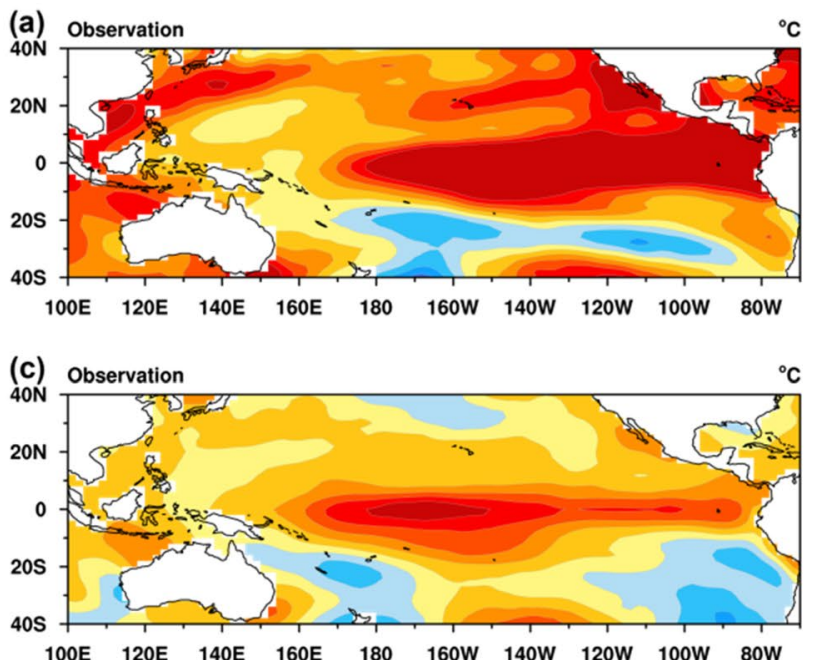
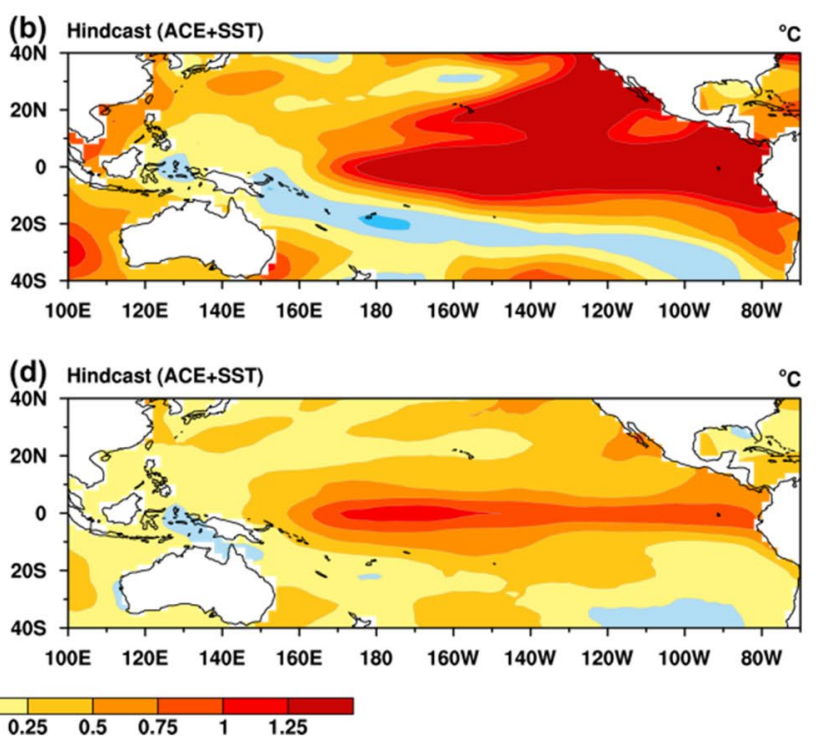

Fig. 16 Spatial distribution of the observed and predicted SST anomalies $\left({ }^{\circ} \mathrm{C}\right)$ during El Niño events from November to January in the period 2000-2018. a Composite of the observed SST anomalies (shading) during EP El Niño. b As in (a), but for the predicted SST anomalies from the ACE + SST model. $\mathbf{c}, \mathbf{d}$ As in $(\mathbf{a}, \mathbf{b})$, but for CP El Niño 

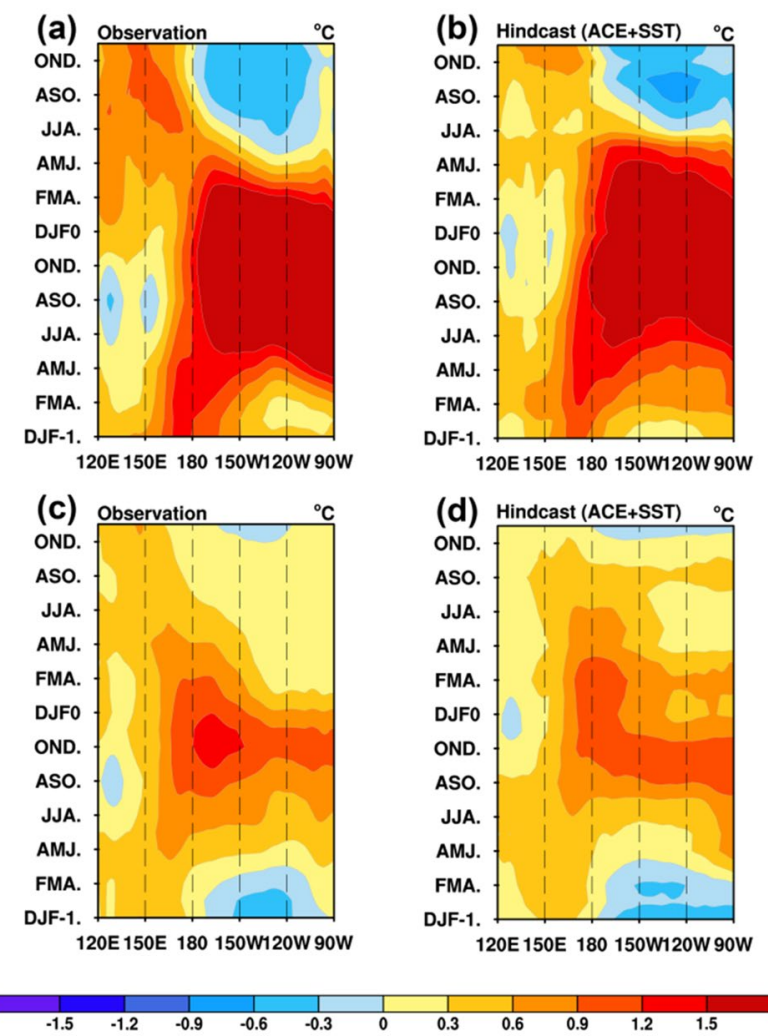

Fig. 17 As in Fig. 16, but for spatial evolution of SST anomalies

where $\mathrm{SST}^{*}{ }_{\mathrm{i}-3}$ is the standardized SST at the $(i-3)$ th month, andc $_{4}, \mathrm{c}_{5}, \mathrm{c}_{6}, \mathrm{~d}_{1}, \mathrm{~d}_{2}, \mathrm{~d}_{3}$ andg $\mathrm{g}_{4}, \mathrm{~g}_{5}, \mathrm{~g}_{6}$ are the regression coefficients and constants.

\section{- Correction to the ACE +SST model}

Previous study (Wang et al. 2019b) has pointed the error of the new model predicted skill would increase because of the persistence of SST, especially in the development stage of ENSO. Hence, similar to the method applied by Wang et al. (2019b), the leave-one-out cross-validation (LOOCV) (Grantz et al. 2005; Regonda et al. 2006) is employed to correct preliminarily this error (The detailed description of LOO-CV has been shown in Wang et al. 2019b). Then, the correction $\varepsilon_{1}$ at each grid will be obtained. Here, $\varepsilon_{1}$ depends on the base period mentioned above. Moreover, the effect of TCs on SST at each grid doesn't keep unchanged throughout the whole period, but varies with the ENSO development. To further reduce error and obtain a more exact forecast, the SST anomaly during the training period is divided into four cases to be corrected according to the variation of predictor variable $\mathrm{SST}^{*}$ at each grid: Case I, $\mathrm{SST}_{\mathrm{i}-3} \geq \mathrm{SST}_{\mathrm{i}-4}$ and $\mathrm{SST}_{\mathrm{i}-3} \geq 0$; Case II, $\mathrm{SST}_{\mathrm{i}-3} \geq \mathrm{SST}_{\mathrm{i}-4}$
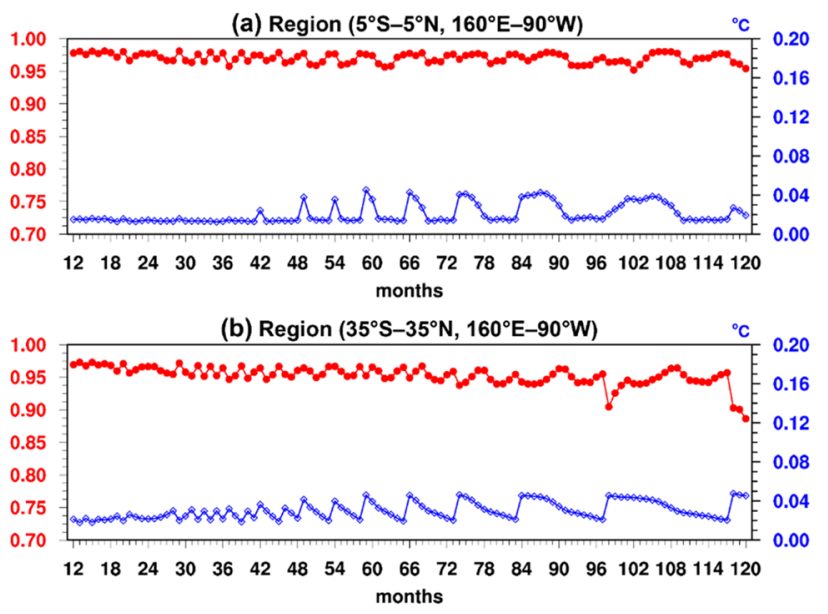

Fig. 18 Spatial correlation coefficient and RMSE $\left({ }^{\circ} \mathrm{C}\right)$ between the observed and predicted three-month running mean SST anomaly from the ACE + SST model using the method of Leave-P-out CrossValidation (see Sect. 2). a For the SST anomaly in the region $5^{\circ} \mathrm{S}-5^{\circ}$ $\mathrm{N}, 160^{\circ} \mathrm{E}-90^{\circ} \mathrm{W}$. b For the SST anomaly in the region $35^{\circ} \mathrm{S}-35^{\circ} \mathrm{N}$, $160^{\circ} \mathrm{E}-90^{\circ} \mathrm{W}$. The $x$-axis represents the time interval in hindcasting
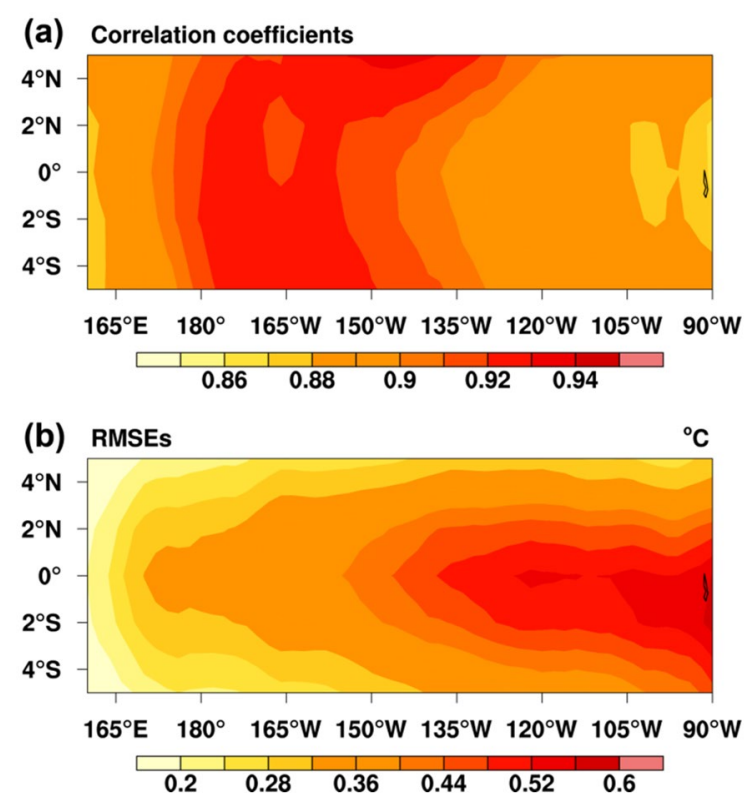

Fig. 19 Correlation coefficient and RMSE $\left({ }^{\circ} \mathrm{C}\right)$ between the observed and predicted running 3-month mean SST anomaly $\left(5^{\circ} \mathrm{S}-5^{\circ} \mathrm{N}, 160^{\circ}\right.$ $\mathrm{E}-90^{\circ} \mathrm{W}$ ) from the ACE + SST model at each grid cell using the method of Leave-P-out Cross-Validation (see Sect. 2. a Correlation coefficients. b RMSEs

and $\mathrm{SST}_{\mathrm{i}-3}<0$; Case III, $\mathrm{SST}_{\mathrm{i}-3}<\mathrm{SST}_{\mathrm{i}-4}$ and $\mathrm{SST}_{\mathrm{i}-3} \geq 0$; Case IV, N3.4 $4_{-3}<\mathrm{SST}_{\mathrm{i}-4}$ and $\mathrm{SST}_{\mathrm{i}-3} \geq 0$. Thus, four different corrected values $\left(\varepsilon_{2}\right)$ are obtained for the four cases. And the ACE + SST model is built as follows: 


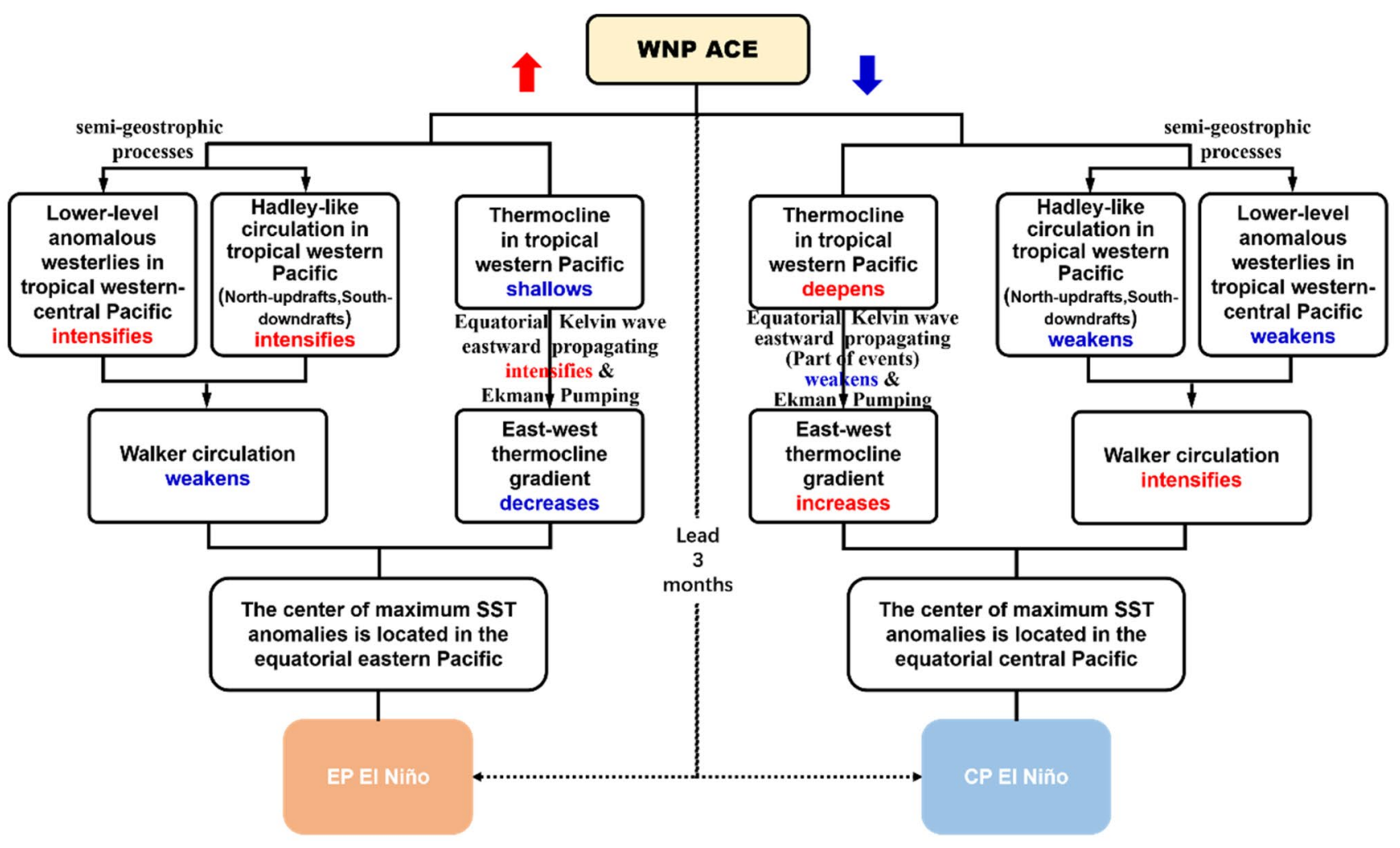

Fig. 20 Schematic diagram of modulation of the El Niño diversity by WNP TCs (all processes are with respective to the composite situation of all El Niño)

$$
\left\{\begin{array}{lll}
S S T_{i}=c_{4} A C E_{i-3}^{*}+d_{1} S S T_{i-3}^{*}+g_{4}+\varepsilon, & N 3.4_{i-3} \geq 0.5, A C E\left(10^{\circ}-20^{\circ} N, 135^{\circ}-170^{\circ} E\right) \\
S S T_{i}=c_{5} A C E_{i-3}^{*}+d_{2} S S T_{i-3}^{*}+g_{5}+\varepsilon, & \left|N 3.4_{i-3}\right|<0.5, A C E\left(10^{\circ}-20^{\circ} N, 135^{\circ}-155^{\circ} E\right) \\
S S T_{i}=c_{6} A C E_{i-3}^{*}+d_{3} S S T_{i-3}^{*}+g_{6}+\varepsilon, & N 3.4_{i-3} \leq-0.5, A C E\left(10^{\circ}-25^{\circ} N, 130^{\circ}-155^{\circ} E\right)
\end{array}\right.
$$

where $\varepsilon$ depends on the case, $\varepsilon=\varepsilon_{1}+\varepsilon_{2}$.

Funding This work was jointly supported by the National Natural Science Foundation of China (NSFC, 42105014 and 41530424) projects, Shandong Natural Science Foundation Project (ZR2019ZD12), Postdoctoral Science Foundation of China (2021T140302, 2021M701652) and Fundamental Research Funds for the Central Universities (201962009).

Availability of data and material Tropical cyclone data is available at https://www.ncdc.noaa.gov/ibtracs/. Monthly sea surface temperature is available at https://www.esrl.noaa.gov/psd/data/gridded/data.noaa. ersst.v5.html. Ocean variables is available at http://apdrc.soest.hawaii. edu/datadoc/soda_2.2.4.php. Monthly wind and geopotential height data are available at https://www.esrl.noaa.gov/psd/. The multi-model ENSO forecast data is available at http://iri.columbia.edu/ forecast/ ensofcst/Data/.

Code availability Computer code used for the analysis was written in NCL, all types of figures that occur in this study can be found in NCL application examples (available online at https://www.ncl.ucar.
edu/Applications/). More specific codes in this study are available to readers upon request.

\section{Declarations}

Conflicts of interest The authors declare no competing interests.

Open Access This article is licensed under a Creative Commons Attribution 4.0 International License, which permits use, sharing, adaptation, distribution and reproduction in any medium or format, as long as you give appropriate credit to the original author(s) and the source, provide a link to the Creative Commons licence, and indicate if changes were made. The images or other third party material in this article are included in the article's Creative Commons licence, unless indicated otherwise in a credit line to the material. If material is not included in the article's Creative Commons licence and your intended use is not permitted by statutory regulation or exceeds the permitted use, you will need to obtain permission directly from the copyright holder. To view a copy of this licence, visit http://creativecommons.org/licenses/by/4.0/. 


\section{References}

Alexander MA, Blade I, Newman M, Lanzante JR, Lau NC, Scott JD (2002) The atmospheric bridge: the influence of ENSO teleconnections on air-sea interaction over the global oceans. J Clim 15:2205-2231

An SI (2008) Interannual variations of the tropical ocean instability wave and ENSO. J Clim 21:3680-3686

Ashok K, Behera SK, Rao SA, Weng HY, Yamagata T (2007) El Niño Modoki and its possible teleconnection. J Geophys Res-Oceans 112:C11007

Battisti DS, Hirst AC (1989) Interannual variability in a tropical atmosphere ocean model-influence of the basic state, ocean geometry and nonlinearity. J Atmos Sci 46:1687-1712

Bell GD, Halpert MS, Schnell RC, Higgins RW, Lawrimore J, Kousky VE, Tinker R, Thiaw W, Chelliah M, Artusa A (2000) Climate assessment for 1999. Bull Am Meteorol Soc 81:S1-S50

Bjerknes J (1969) Atmospheric teleconnections from the equatorial Pacific. Mon Weather Rev 97:163-172

Carton JA, Giese BS (2008) A reanalysis of ocean climate using Simple Ocean Data Assimilation (SODA). Mon Weather Rev 136:2999-3017

Chan JCL (2000) Tropical cyclone activity over the western North Pacific associated with El Niño and La Niña events. J Clim 13:2960-2972

Chen DK, Lian T, Fu CB, Cane MA, Tang YM, Murtugudde R, Song XS, Wu QY, Zhou L (2015) Strong influence of westerly wind bursts on El Niño diversity. Nat Geosci 8:339-345

Ding RQ, Li JP, Tseng YH, Sun C, Xie F (2017) Joint impact of North and South Pacific extratropical atmospheric variability on the onset of ENSO events. J Geophys Res-Atmos 122:279-298

Ding RQ, Tseng YH, Li JP, Sun C, Xie F, Hou ZL (2019) Relative contributions of North and South Pacific sea surface temperature anomalies to ENSO. J Geophys Res-Atmos 124:6222-6237

Emanuel K (2003) Tropical cyclones. Annu Rev Earth Planet Sci 31:75-104

Fedorov AV, Hu SN, Lengaigne M, Guilyardi E (2015) The impact of westerly wind bursts and ocean initial state on the development, and diversity of El Niño events. Clim Dyn 44:1381-1401

Feng JX, Wu ZH, Zou XL (2014) Sea surface temperature anomalies off Baja California: a possible precursor of ENSO. J Atmos Sci 71:1529-1537

Gebbie G, Eisenman I, Wittenberg A, Tziperman E (2007) Modulation of westerly wind bursts by sea surface temperature: A semistochastic feedback for ENSO. J Atmos Sci 64:3281-3295

Geisser S (1975) The predictive sample reuse method with applications. J Am Stat Assoc 70:320-328

Giese BS, Harrison DE (1991) Eastern equatorial Pacific response to 3 composite westerly wind types. J Geophys Res-Oceans 96:3239-3248

Grantz K, Rajagopalan B, Clark M, Zagona E (2005) A technique for incorporating large-scale climate information in basin-scale ensemble streamflow forecasts. Water Resour Res 41:W10410

Guo YP, Tan Z-M (2018a) Impacts of the boreal spring Indo-Pacific warm pool hadley circulation on tropical cyclone activity over the western North Pacific. J Clim 31:1361-1375

Guo YP, Tan Z-M (2018b) Westward migration of tropical cyclone rapid-intensification over the Northwestern Pacific during short duration El Niño. Nat Commun 9:1507

Harrison DE, Vecchi GA (1997) Westerly wind events in the tropical Pacific, 1986-95. J Clim 10:3131-3156

Hendon HH, Lim E, Wang GM, Alves O, Hudson D (2009) Prospects for predicting two flavors of El Niño. Geophys Res Lett 36:L19713
Hu Z-Z, Kumar A, Jha B, Wang W, Huang B, Huang B (2012) An analysis of warm pool and cold tongue El Niño: air-sea coupling processes, global influences, and recent trends. Clim Dyn 38:2017-2035

Huang BY, Thorne PW, Banzon VF, Boyer T, Chepurin G, Lawrimore JH, Menne MJ, Smith TM, Vose RS, Zhang HM (2017) Extended Reconstructed Sea Surface Temperature, version 5 (ERSSTv5): Upgrades, validations, and intercomparisons. J Clim 30:8179-8205

Jeong HI, Lee DY, Ashok K, Ahn JB, Lee JY, Luo JJ, Schemm JKE, Hendon HH, Braganza K, Ham YG (2012) Assessment of the APCC coupled MME suite in predicting the distinctive climate impacts of two flavors of ENSO during boreal winter. Clim Dyn 39:475-493

Jin F-F (1997a) An equatorial ocean recharge paradigm for ENSO. 1. Conceptual model. J Atmos Sci 54:811-829

Jin F-F (1997b) An equatorial ocean recharge paradigm for ENSO.2. A stripped-down coupled model. J Atmos Sci 54:830-847

Kalnay E, Kanamitsu M, Kistler R, Collins W, Deaven D, Gandin L, Iredell M, Saha S, White G, Woollen J, Zhu Y, Chelliah M, Ebisuzaki W, Higgins W, Janowiak J, Mo KC, Ropelewski C, Wang J, Leetmaa A, Reynolds R, Jenne R, Joseph D (1996) The NCEP/NCAR 40-year reanalysis project. B Am Meteorol Soc 77:437-471

Kao HY, Yu JY (2009) Contrasting eastern-Pacific and central-Pacific types of ENSO. J Climate 22:615-632

Keen RA (1982) The role of cross-equatorial tropical cyclone pairs in the Southern Oscillation. Mon Weather Rev 110:1405-1416

Knutson TR, McBride JL, Chan J, Emanuel K, Holland G, Landsea C, Held I, Kossin JP, Srivastava AK, Sugi M (2010) Tropical cyclones and climate change. Nat Geosci 3:157-163

Kossin JP (2018) A global slowdown of tropical-cyclone translation speed. Nature 558:104-107

Kossin JP, Emanuel KA, Vecchi GA (2014) The poleward migration of the location of tropical cyclone maximum intensity. Nature 509:349-352

Kug JS, Ham YG (2011) Are there two types of La Niña? Geophys Res Lett 38:L16704

Kug JS, Jin F-F, An SI (2009) Two types of El Niño Events: cold tongue El Niño and warm pool El Niño. J Clim 22:1499-1515

Lau NC, Nath MJ (1996) The role of the "atmospheric bridge" in linking tropical Pacific ENSO events to extratropical SST anomalies. J Clim 9:2036-2057

Li JP, Swinbank R, Grotjahn R, Volkert H (2016) Dynamics and predictability of large-scale, high-impact weather and climate events. Cambridge University Press, p 370

Li JP, Zheng F, Sun C, Feng J, Wang J (2019) Pathways of influence of the Northern Hemisphere mid-high latitudes on East Asian climate: a review. Adv Atmos Sci 36:902-921

Lian T, Chen DK, Tang YM, Wu QY (2014) Effects of westerly wind bursts on El Niño: a new perspective. Geophys Res Lett 41:3522-3527

Liu ZY, Yang HJ (2003) Extratropical control of tropical climate, the atmospheric bridge and oceanic tunnel. Geophys Res Lett 30:1230

Lian T, Chen D, Tang Y, Liu X, Feng J, Zhou L (2018) Linkage between westerly wind bursts and tropical cyclones. Geophys Res Lett 45:11431-11438

Moore AM, Kleeman R (1999) Stochastic forcing of ENSO by the intraseasonal oscillation. J Climate 12:1199-1220

Picaut J, Masia F, duPenhoat Y (1997) An advective-reflective conceptual model for the oscillatory nature of the ENSO. Science 277:663-666

Regonda SK, Rajagopalan B, Clark M, Zagona E (2006) A multimodel ensemble forecast framework: application to spring seasonal flows in the Gunnison River Basin. Water Resour Res 42:W09404 
Ren HL, Jin F-F, Tian B, Scaife AA (2016) Distinct persistence barriers in two types of ENSO. Geophys Res Lett 43:10973-10979

Suarez MJ, Schopf PS (1988) A delayed action oscillator for ENSO. J Atmos Sci 45:3283-3287

Tang Y, Yu B (2008) MJO and its relationship to ENSO. J Geophys Res-Atmos 113:D14106

Tang YM, Zhang RH, Liu T, Duan WS, Yang DJ, Zheng F, Ren HL, Lian T, Gao C, Chen DK, Mu M (2018) Progress in ENSO prediction and predictability study. Natl Sci Rev 5:826-839

Wang CZ (2001) A unified oscillator model for the El Niño-Southern Oscillation. J Clim 14:98-115

Wang QY, Li JP (2022) The feedback of tropical cyclones on El Niño diversity Part I: phenomenon. Clim Dyn. https://doi.org/10.1007/ s00382-021-06122-y

Wang B, Barcilon A, Fang Z (1999a) Stochastic dynamics of El NiñoSouthern Oscillation. J Atmos Sci 56:5-23

Wang CZ, Weisberg RH, Virmani JI (1999b) Western Pacific interannual variability associated with the El Niño Southern oscillation. J Geophys Res-Oceans 104:5131-5149

Wang CZ, Deser C, Yu J-Y, DiNezio P, Clement A (2016) El NiñoSouthern Oscillation (ENSO): a review. In: Glymn P, Manzello D, Enochs I (eds) In coral reefs of the Eastern Pacific. Springer Science Publisher, pp 85-106

Wang QY, Li JP, Li YJ, Zhang JW, Zheng JY (2018) Modulation of tropical cyclogenesis location and frequency over the Indo-western North Pacific by the intraseasonal Indo-western Pacific convection oscillation during the boreal extended summer. J Climate 31:1435-1450

Wang QY, Li JP, Li YJ, Xue JQ, Zhao S, Xu YD, Wang YH, Zhang YZ, Dong D, Zhang JW (2019a) Modulation of tropical cyclone tracks over the western North Pacific by intra-seasonal Indo-western
Pacific convection oscillation during the boreal extended summer. Clim Dyn 52:913-927

Wang QY, Li JP, Jin F-F, Chan JCL, Wang CZ, Ding RQ, Sun C, Zheng F, Feng J, Xie F, Li YJ, Li F, Xu YD (2019b) Tropical cyclones act to intensify El Niño. Nat Commun 10:3793

Weisberg RH, Wang CZ (1997) A western Pacific oscillator paradigm for the El Niño Southern Oscillation. Geophys Res Lett 24:779-782

Yang S, Li ZN, Yu JY, Hu XM, Dong WJ, He S (2018) El NiñoSouthern Oscillation and its impact in the changing climate. Natl Sci Rev 5:840-857

Yu JY, Kao HY, Lee T (2010) Subtropics-related interannual sea surface temperature variability in the central equatorial Pacific. J Clim 23:2869-2884

Zhan RF, Wang YQ, Zhao JW (2017) Intensified Mega-ENSO has increased the proportion of intense tropical cyclones over the western Northwest Pacific Since the Late 1970s. Geophys Res Lett 44:11959-11966

Zhang RH (2014) Effects of tropical instability wave (TIW)-induced surface wind feedback in the tropical Pacific Ocean. Clim Dyn 42:467-485

Zheng YX, Zhang RH, Bourassa MA (2014) Impact of East Asian winter and Australian summer monsoons on the enhanced surface westerlies over the western tropical Pacific Ocean preceding the El Niño Onset. J Clim 27:1928-1944

Publisher's Note Springer Nature remains neutral with regard to jurisdictional claims in published maps and institutional affiliations. 